\title{
The Future Mandate of the Constitution of Slovenia: A Potent Tradition Under Strain
}

\author{
Samo Bardutzky
}

\begin{abstract}
The 1991 Constitution of Slovenia belongs to the category of strong constitutions, with a detailed list of rights. The report informs that the concept of the rule of law mostly draws on German commentaries on the constitutional Rechtsstaat, and its main elements are expressly entrenched in constitutional provisions. Particularly notable are the detailed limits on the power of the state in prosecuting crimes and detailed guarantees for judicial protection, which are identified as more extensive than those in the ECHR and the EU Charter. The constitutional amendments for EU and international co-operation contain a clause on the respect for human rights, democracy and the rule of law. The report extensively documents areas where the above, potent constitutional tradition has come under strain in the context of EU law. The examples range from the Data Retention Directive - the implementation of which was rushed under the threat of EU fines - to concerns by scholars with regard to Viking Line and Laval that the Constitution limits the limitations on fundamental rights, and that economic freedoms ought not to trump fundamental rights despite the status that the former have been accorded by the ECJ. A particularly acute awareness emerges with regard to the changing role of courts in European Arrest Warrant cases, with warnings by lawyers about the danger of instrumentalising judges, and transforming judges into 'ticking box' automatons neglecting their duty of safeguarding fundamental rights. The constitutional protection of the right to water has also been debated with reference to an EU directive. More broadly, the report expresses concern that because of the different approach to judicial review of EU measures, the heavy
\end{abstract}

The author is Assistant Professor of Constitutional Law at the University of Ljubljana, Slovenia; at the time of writing Research Associate, University of Kent, United Kingdom. e-mail: S.Bardutzky@pf.uni-lj.si.

The author is indebted to Anneli Albi, Mojca Plesničar, Andraž Zidar, Peter Pavlin and Maria Gomes for their careful reading of the draft text and valuable comments, and very grateful to Marjan Kos for his thorough and enthusiastic research assistance.

All websites accessed 1 December 2015. Text submitted 20 July 2015.

S. Bardutzky ( $\square)$

University of Ljubljana, Ljubljana, Slovenia

e-mail: S.Bardutzky@pf.uni-lj.si

(C) The Author(s) 2019

A. Albi and S. Bardutzky (eds.), National Constitutions in European

and Global Governance: Democracy, Rights, the Rule of Law,

https://doi.org/10.1007/978-94-6265-273-6_15 
books with commentary on the Constitution are no longer carried by civil servants to meetings to identify constraints on the exercise of public power placed by the Constitutional Court.

Keywords The Constitution of Slovenia - Constitutional amendments regarding EU and international co-operation - The Slovenian Constitutional Court

Constitutional review statistics and grounds - German influences on the rule of law and the constitutional Rechtsstaat - Limitation of rights - Referendums on accession and on euro crisis measures - European Arrest Warrant, judicial review and defence rights - The changing role of courts - Data Retention Directive and the threat of EU fines - Article 53 EU Charter and the question of a higher standard of protection - The constitutional right to water

\section{Constitutional Amendments Regarding EU Membership}

\subsection{Constitutional Culture}

1.1.1 The adoption of the Constitution of the Republic of Slovenia in $1991^{1}$ followed two tectonic changes. The first was the transition from a non-democratic political system with socialist consensus economics and where the pivotal role in society was played by the Communist party, to a multi-party democracy, market economy and society based on respect for human rights and fundamental freedoms. $^{2}$ The second change was the declaration of independence from the Socialist Federal Republic of Yugoslavia of which Slovenia was a constituent part. $^{3}$

Stemming from the decision of the Slovenian people to establish independence and democracy, the Constitution belongs to the category of strong constitutions. It possesses a dominant legal character, not only through the establishment of a

\footnotetext{
${ }^{1}$ Ustava Republike Slovenije in Slovene. The original text is published in the Official Journal of the Republic of Slovenia (Uradni list Republike Slovenije, hereinafter UL) 33/91-I, with subsequent amendments in UL 42/97, 66/2000, 24/03, 69/04, 68/06 in 47/13. I have drawn on the English translation available from the website of the Constitutional Court, http://www.us-rs.si/en/ about-the-court/legal-basis/constitution/.

21989 Amendments XIII-XXXIV to the 1974 Constitution of the Socialist Republic of Slovenia introduced several elements of economic liberalisation, while the 1990 Amendments XCI-XCV provided for a basis for the first democratic election to the tricameral Assembly of the Republic, which took place in April 1990.

${ }^{3}$ The Basic Constitutional Charter on the Sovereignty and Independence of the Republic of Slovenia (UL 1/91-I), proclaiming Slovenia to be an independent state on 25 June 1991 (4 months before the adoption of the Constitution), continues to be considered a 'valid constitutional act' of Slovenian constitutional law by the Constitutional Court (CCRS Rm-1/09, Opinion of 18 March 2010, UL 25/2010).
} 
special Constitutional Court charged with safeguarding the Constitution and vested with the power to annul legislation (Chap. VIII), ${ }^{4}$ but also through the subjection of the courts (Art. 125) and the public administration (Art. 120(2)) to the Constitution. Furthermore, human rights and fundamental freedoms are exercised directly on the basis of the Constitution (Art. 15(3), emphasis added). This is complemented by the detailed, almost technical phrasing of some of the constitutional guarantees (e.g. Art. 20(2)).

However, some of the solutions adopted in the 1991 Constitution also draw on the tradition of the pre-1991 constitutional system. The superior position of the representative assembly in relation to the other branches of government serves as a simple example. To what extent the aspiration of the Constitution to regulate or at least broadly define the country's economic and social system can be understood as a legacy of the pre-1991 system is a more complex issue, capable of influencing the understanding of the nature and content of the Slovenian constitutional identity. ${ }^{5}$ The gradual legal transition from the old to the new constitutional system (the old 1974 constitution was amended in 1989 and 1990 before the adoption of a new constitutional text) is an additional argument against viewing the Constitution as a revolutionary constitution. ${ }^{6}$ In that sense, it is somewhat helpful to invoke Rosenfeld's 'pacted transition model of constitution-making, ${ }^{7}$ but only to appreciate the limits of the categorisation proposed in the questionnaire and its relevance for the Slovenian case. ${ }^{8}$

1.1.2 The Constitution is concerned with both the organisation of the state and limiting public power, and both elements of the rationale are important. Regarding the latter, the provisions on human rights and fundamental freedoms, along with some of the central principles of the Constitution, such as the separation of powers, are of pivotal importance. This can be said for lawmaking, where constitutional standards are enforced through the case law of the Constitutional Court, as well as with regard to decision making in the judiciary and the public administration. At the same time, the fact that the democratic system in Slovenia is relatively young means that the constitutional provisions establishing the system of government are frequently invoked in public discussions triggered by events in the everyday political life of the country. The financial crisis has to a significant extent also led to a political crisis resulting in unstable governments, snap elections and referendums. In many cases these events have been unprecedented in the history of the nation, sparking the constitutional imagination of the general and professional public.

We can add to the discussion on the rationale of the Constitution that it also purports to lay down the fundamental features of the socio-economic system

\footnotetext{
${ }^{4}$ Plesničar and Modic 2007.

${ }^{5}$ The 'third rationale' of the Constitution (Ch. III) is outlined below in Sect. 1.1.2.

${ }^{6}$ See above n. 2.

${ }^{7}$ Rosenfeld 2009, pp. 197-201.

${ }^{8}$ Rosenfeld's categorisation would also struggle to provide an adequate framework within which the Slovenian path to constitutionalism at the end of the XX century can be understood.
} 
(Chap. III: Economic and Social Relations). This extends beyond protecting economic and social human rights (some of the third generation human rights, e.g. the right to social security including old-age pension, health care and education, are also entrenched in Chap. II 'Bill of Rights'). The provisions of Chap. III further protect collective industrial action, ${ }^{9}$ natural and cultural heritage, free economic initiative within the boundaries of the public interest, etc. Some of the provisions in the chapter enjoy the status of a justiciable human right (e.g. right to a healthy living environment, Art. 72). ${ }^{10}$ Other provisions (e.g. on housing, Art. 78) have a programmatic character. ${ }^{11}$ Proposed amendments to Chap. III are discussed below in Sect. 3.6.

\subsection{The Amendment of the Constitution in Relation to the European Union}

1.2.1 The first EU-related constitutional reform was the 1997 amendment of Art. 68, the provision on acquisition of land by foreigners. The 'Europe Agreement', an association agreement between the members of the then European Communities and Slovenia, envisaged a liberalisation of land acquisition by foreigners. ${ }^{12}$ The agreement was found partly unconstitutional by the Constitutional Court, which triggered an amendment process. ${ }^{13}$ With the constitutional reform, land acquisition was liberalised and subjected to conditions laid down by a statute or an international agreement. $^{14}$

The central EU-related constitutional reform took place in 2003, which saw yet another amendment of Art. 68, an amendment of Art. 47 (the absolute prohibition on extradition of a national citizen was relativised) and the introduction of the 'Europe clause' (Art. 3.a). ${ }^{15}$ The latter allows for transfer of the exercise of part of Slovenia's sovereign rights to international organisations by virtue of ratification of an international treaty (para. 1; see Sect. 1.3.1). It also provides for a referendum that can be called prior to the ratification of such a treaty (para. 2; see Sect. 1.4.2). Article 3.a also refers to the law of the international organisations mentioned in

\footnotetext{
${ }^{9}$ See also Sect. 2.2.1.

${ }^{10}$ Čebulj 2011, p. 1027.

${ }^{11}$ Kresal 2011, p. 1080.

${ }^{12}$ Europe Agreement establishing an association between the European Communities and their Member States, acting within the framework of the European Union, of the one part, and the Republic of Slovenia, of the other part, [1999] OJ L 51/3.

${ }^{13}$ CCRS Rm-1/97 (OdIUS VI, 86).

${ }^{14}$ Constitutional Act amending Art. 68 of the Constitution of the Republic of Slovenia, UL 42/97. See also Ribičič 2003, pp. 31-34.

${ }^{15}$ Constitutional Act amending Chapter 1 and Arts. 47 and 68 of the Constitution of the Republic of Slovenia, UL 24/03.
} 
Para. 1 (Para. 3; see Sect. 1.3.1) and entrenches the rights of Parliament in the new situation arising post-accession (Para. IV; see Sect. 1.4.1).

In 2013, a 'fiscal rule' was introduced in Art. 148 in order to comply with the obligations undertaken by Slovenia under the Treaty on Stability, Coordination and Governance. ${ }^{16}$ The rule requires that the revenues and expenditures of the state budget must in principle be balanced in the medium term, without borrowing (or revenues must exceed expenditures). Article 148 foresees that a statute, adopted by the same majority as required for a constitutional amendment, will lay down the way in which the fiscal rule works in more detail. ${ }^{17}$

1.2.2 A proposal to initiate the procedure for amending the Constitution can be lodged by twenty deputies of the National Assembly, the Government or at least thirty thousand voters. The National Assembly votes upon such proposals. If a proposal is supported by two-thirds of the deputies present, the procedure to amend the Constitution is initiated (Art. 168 Constitution).

A successful vote is followed by a procedure in the Constitutional Commission, a body of the National Assembly. The Commission is composed of deputies from the political parties, proportionally to the size of each party's parliamentary group in the National Assembly. The Commission, however, also convenes an ad hoc expert group, typically composed of law professors.

If the idea for the amendment of the Constitution enjoys sufficient support in the Constitutional Commission, the latter drafts the amendment for the National Assembly. Importantly, the drafting is thus withdrawn from the influence of the subject that initially triggered the procedure (e.g. the Government). The National Assembly (in plenary session) may not change the text (Arts. 172-181 Rules of Procedure of the National Assembly; hereinafter PoDZ-1). ${ }^{18}$

The proposal must be adopted by a two-thirds majority of all deputies. An amendment can still be subjected to a constitutional referendum if one-third of the deputies so require (Arts. 169-170 Constitution). This is a relatively onerous requirement, and no such referendum has yet been held. ${ }^{19}$

1.2.3 The prevalent view was that the accession to the EU required a constitutional amendment. The principal reasons were threefold. The first reason was that transfer

\footnotetext{
${ }^{16}$ Constitutional Act amending Art. 148 of the Constitution of the Republic of Slovenia (UZ148), UL $47 / 13$.

${ }^{17}$ I.e. the mode and timeframe of exercising the rule, criteria to determine whether exceptional circumstances prevent it, etc. This statute was to be adopted within 6 months of the constitutional reform (Sect. II UZ148). The draft Fiscal Rule Act (ZFisP-1) was still in parliamentary procedure in June 2015 (EPA 0227-VII).

${ }^{18}$ Rules of Procedure of the National Assembly, UL 92/07, 105/10, 80/13.

${ }^{19}$ Kaučič ascribes this difficultly attainable quorum of deputies to a drafting error. Kaučič $2011 \mathrm{~b}$, p. 1545.
} 
of a part of sovereignty to another entity under an international treaty would be unconstitutional without express authorisation in the text of the Constitution. Secondly, without a collision rule between EU law and national constitutional law, the Constitutional Court could find itself in a position where it would have to declare EU law unconstitutional. Thirdly, given the symbolic and constitutive value of sovereignty, accession to the EU required a high level of transparency in constitutional lawmaking. ${ }^{20}$

Despite the fact that Art. 3.a was adopted in order to provide a constitutional basis for the entry of Slovenia into the EU, the text of the article does not expressly refer to it. It instead refers to an international organisation. Matej Avbelj traces this approach to constitutional drafting back to the 'international law' approach to the understanding of the EU, which does not sufficiently distinguish the EU from the sphere of international law and international organisations. ${ }^{21}$

At the time of drafting, a more concretised text was also on the table, explicitly referring to the EU. It seems that the abstract, 'minimalist' approach was chosen for the following reasons. First, a broad phrasing can accommodate the different outcomes of the evolution of the legal nature of the EU and the related terminology (Community/Union). Secondly, the Slovenian membership was not completely certain at the time of drafting. Thirdly, the abstract phrasing of the constitutional provisions, capable of accommodating a wide range of legal and factual situations, was considered to be part of the Slovenian constitutional tradition. Moreover, it seems that there was an important time factor that in the end curtailed discussions in the Constitutional Commission of the National Assembly. ${ }^{22}$

The abstract approach to the wording of the 'Europe clause' was advocated by the Government that initiated the amendment procedure. An increasing number of experts advised against the approach taken by the Government, and this opposing view also became prevalent in the expert group of the Constitutional Commission. However, the expert group failed in its attempt to replace the abstract approach with a compromise 'combined' approach in the final stages of the procedure in the Constitutional Commission. Under the combined approach, there would have been a clause that explicitly authorised the transfer of the exercise of part of sovereignty to the EU, but also another clause which would have abstractly allowed for the exercise of sovereignty to be partly transferred to an international organisation or international tribunal. ${ }^{23}$

1.2.4 There have been no further amendment proposals in relation to the EU that have not materialised in practice.

\footnotetext{
${ }^{20}$ Cerar 2003b, pp. 6-7.

21 Avbelj 2012b, p. 6.

${ }^{22}$ Cerar 2003a, pp. 1463-1474; see also Sect. 1.4.2.

${ }^{23}$ Cerar 2003a, pp. 1464-1465.
} 


\subsection{Conceptualising Sovereignty and the Limits to the Transfer of Powers}

1.3.1 Transfer of the exercise of a part of Slovenia's sovereign rights to 'international organisations' and the conditions therefor are envisaged in Art. 3.a(1):

Pursuant to a treaty ratified by the National Assembly by a two-thirds majority vote of all deputies, Slovenia may transfer the exercise of part of its sovereign rights to international organisations which are based on respect for human rights and fundamental freedoms, democracy, and the principles of the rule of law and may enter into a defensive alliance with states which are based on respect for these values.

Hence, according to the text of the Constitution, only the exercise of sovereignty and not sovereignty itself can be transferred. Behind this wording is arguably the idea that transfer is not eternal in the sense that Slovenia could at some point in the future resume exercising its sovereignty. However, this phrasing and its explanation have been met with scepticism. ${ }^{24}$ Notably, the majority required for the ratification of an Art. 3.a treaty is the same as the majority required for a constitutional amendment.

In line with the abstract 'international organisation' approach of Art. 3.a, the text of para. 3 provides that

[1] egal acts and decisions adopted within international organisations to which Slovenia has transferred the exercise of part of its sovereign rights shall be applied in Slovenia in accordance with the legal regulation of these organisations.

This accommodates the supremacy and direct effect of EU law in the Slovenian constitutional order.

1.3.2 The key decision in the case law of the Slovenian Constitutional Court on sovereignty is its 2003 decision on the 'Vatican Agreement' ${ }^{25}$ Adopted after Art. 3. a had already been inserted into the Constitution (albeit not on this basis), it emphasises that neither the internal nor the external element of sovereignty are absolute, the latter because of public international law. Sovereignty prevents the state from transferring sovereign powers to other states or institutions; Art. 3.a is the only exception (allowing for transfer of the exercise of sovereign powers). ${ }^{26}$

The position in the Vatican Agreement decision served as the basis for the recent State Holding \& Bank Stability Referendum decision of the Constitutional Court, with which it prevented the holding of a legislative referendum on two anti-crisis measures. ${ }^{27}$ Avbelj has commented that in this decision, the Court demonstrated its awareness that Slovenia will have to take into consideration the existence of a host

\footnotetext{
${ }^{24}$ Cerar 2003a, pp. 1471-1474.

${ }^{25}$ Agreement between the Republic of Slovenia and the Holy See on legal issues, UL 13/2004.

${ }^{26}$ CCRS Rm-1/02, UL 118/2003, paras. 22- 24.

${ }^{27}$ CCRS U-II-1/12, U-II-2/12, UL 102/2012.
} 
of transnational actors and learn to react to their impulses if it is to retain its 'legal and political' sovereignty. ${ }^{28}$

The National Assembly opposed the referendum by claiming that failure to enact the Act on the Measures to Strengthen Bank Stability (ZUKSB) ${ }^{29}$ would push Slovenia into a bail-out situation. European and IMF financial assistance would lead to an encroachment upon sovereignty contrary to Art. 3.a. The Constitutional Court rejected this view and held that the sovereignty of Slovenia entails the prerogative to conclude international agreements. A financial assistance agreement with the IMF would not per se amount to an impermissible encroachment on sovereignty, rather it is the substance of the international agreement that would need to be examined.

1.3.3 The text of the Constitution itself sets a limit to transfer of the exercise of sovereign rights. Such transfer may only be to an international organisation that is based on (1) respect for human rights and fundamental freedoms, (2) democracy and (3) the principles of the rule of law (pravna država ${ }^{30}$ in Slovenian). This provision was modelled after Art. 23(1) of the German Grundgesetz and can be understood as introducing a kind of causa for accession to the EU. ${ }^{31}$ The selection of the three substantive limits by the constitutional legislature (human rights, democracy, pravna država) was careful and reflects the general perception of what the essential constitutional principles are. Each of these three principles is unattainable unless all three are respected, while at the same time they set limits to one other. ${ }^{32}$

The limits to transfer cannot be understood as empowering the Constitutional Court to reject the application of individual EU legal norms that would be found incompatible with the Constitution. The limits would probably only be invoked should the EU at some point 'in its fundaments' digress from these constitutional principles. In such a scenario, the limits could provide a legal basis for the Slovenian authorities to reject the application of EU legal acts and refuse to execute decisions of the EU. ${ }^{33}$ Nevertheless, the text prescribing the limits to transfer can serve to infuse the Slovenian court with some self-confidence when it needs to take a stance with regard to the effects of EU law. ${ }^{34}$

1.3.4 The Constitution does not explicitly declare itself supreme, but it does, however, command that all 'statutes, regulations, and other general acts' must be in conformity with it (Art. 153(1)), in reference to domestic legal norms. The Constitution also envisages control of the conformity of treaties with the

\footnotetext{
${ }^{28}$ Avbelj 2013c, p. 6. See also the opinion of Judge Petrič infra n. 150.

${ }^{29}$ UL $105 / 12$.

${ }^{30}$ See Sect. 2.1.3.

${ }^{31}$ Testen 2011, p. 91.

${ }^{32}$ Cerar 2011, pp. 78-79.

${ }^{33}$ Ibid.

${ }^{34}$ Testen 2011, p. 91.
} 
Constitution (discussed below in Sect. 3.4.1). Theoretically then, a review of the constitutionality of a new treaty of EU primary law is not excluded. ${ }^{35}$ When it comes to EU secondary law, the Constitutional Court, citing Foto-Frost, has declared its respect for the exclusive jurisdiction of the Court of Justice (ECJ) over questions of validity. ${ }^{36}$ At the same time, the Court has not relinquished its jurisdiction over domestic legal acts implementing EU law. ${ }^{37}$ As we have recently seen in U-I-295/13 (see Sect. 2.6.1), it seems that the Constitutional Court will exercise this jurisdiction in dialogue with the ECJ. However, the Court has so far refused to choose between the unconditional supremacy of EU law over the Constitution on the one hand and the possibility that EU law would in exceptional circumstances have to give way to the Slovenian Constitution. The Court again refused to rule on this issue in the State Holding \& Bank Stability Referendum case (see Sect. 1.3.2). Notably, in this case the Court found that it did not face a dilemma due to the 'gravitas of the respect for EU law as a value of constitutional law', based on Art. 3. a Constitution. ${ }^{38}$

\subsection{Democratic Control}

1.4.1 The essential guarantee of the participation of the National Assembly in EU affairs is entrenched in the Constitution, establishing a 'Danish model' of the relationship between Parliament and Government in EU affairs. ${ }^{39}$ According to Art. 3.a(4):

In procedures for the adoption of legal acts and decisions in international organisations to which Slovenia has transferred the exercise of part of its sovereign rights, the Government shall promptly inform the National Assembly of proposals for such acts and decisions as well as of its own activities. The National Assembly may adopt positions thereon, which the Government shall take into consideration in its activities. The relationship between the National Assembly and the Government arising from this paragraph shall be regulated in detail by a statute adopted by a two-thirds majority vote of deputies present.

However, should the Government disregard its duties to inform and to take the positions of the National Assembly into consideration, only a political sanction could be imposed. ${ }^{40} \mathrm{~A}$ more detailed system of parliamentary participation is laid down in a statute adopted with a qualified majority of two-thirds of deputies present. $^{41}$

\footnotetext{
${ }^{35}$ See also Nerad 2012, p. 387.

${ }^{36}$ CCRS U-I-113/04, Order of 8 July 2004, UL 83/04, para. 7; Oven 2014, p. 25.

${ }^{37}$ For example in CCRS U-I-65/13, Order of 26 Sept 2013, para. 7.

${ }^{38}$ CCRS U-II-1/12, U-II-2/12, UL 102/2012, para. 53.

${ }^{39}$ Avbelj 2012a, p. 346.

${ }^{40} \mathrm{Grad} 2007$, p. 112.

${ }^{41}$ UL 34/04, 43/10, 107/10. See also Grad 2007, p. 111.
} 
In the Act on Cooperation between the National Assembly and the Government in EU Affairs (ZVSDZVZEU), the National Assembly has recognised that it is the Government that represents Slovenia and furthers its positions in the processes in the institutions of the Union. The Government is independent and accountable in EU affairs, but within the boundaries set by the Constitution, the statute regulating the Government and the ZSDZVZEU (Art. 2). This dominant position of the Government is balanced by the rights of the National Assembly safeguarded in the ZSDZVZEU. The National Assembly, through its standing committees, participates in the formulation of the positions of Slovenia in those EU affairs that would given their substance - otherwise fall within the competence of the National Assembly (Art. 4). The Government's duty to extensively inform is with regard to Art. 4 EU affairs (Arts. 8-9). The Act instructs the National Assembly to discuss any proposed changes to the founding Treaties and adopt a position. A position on the political direction that Slovenia will take in the EU institutions is also to be adopted in a plenary debate once a year (Art. 5).

The ZSDZVZEU only safeguards the rights of the National Assembly and does not foresee any role for Slovenia's weak and unusually composed second chamber of Parliament, the National Council. The latter challenged the ZSDZVZEU before the Constitutional Court, claiming that the Act is incompatible with the Lisbon Treaty (sic). The Court established that the distribution of powers among organs of the state in relation to EU affairs is by and large a matter for national law. Given that the National Council is not mentioned in Art. 3.a, the Court found that the ZSDZVZEU was in conformity with the Constitution. ${ }^{42}$

1.4.2 There has only been one EU-related referendum, held on 23 March 2003. The electorate was asked to vote not only on Slovenian membership in the EU, but also in the North Atlantic Treaty Organization (NATO). ${ }^{43}$ Unlike several other Member States that joined the EU in the 2004 enlargement but had been members of NATO for some time, Slovenians faced two major decisions on the (geo)political course that their country was about to take at exactly the same time. Joining the EU enjoyed significantly broader support than joining NATO. ${ }^{44}$

As was mentioned above (Sect. 1.2.3), time was an important factor in the referendum story. The referendum was called by the National Assembly on 30 January 2003, and the date of the ballot was set. The referendum was called as a consultative referendum, i.e. a referendum without legally binding results for the organs of the state. ${ }^{45}$ Less than a month later, on 27 February 2003, the

\footnotetext{
${ }^{42}$ CCRS U-I-17/11, UL 87/2012.

${ }^{43}$ See Sect. 3.1.1 regarding membership in NATO.

${ }^{44} 89.64 \%$ of the votes cast were in support of EU membership, in comparison to $66.08 \%$ in favour of joining NATO. The turnout was approximately $60 \%$. See National Electoral Commission, Report on the referendum on the accession of Slovenia to the EU, 1 April 2003, http://www.dvkrs.si/files/files/porocilo-o-referendumu-EU.pdf.

${ }^{45}$ Ordinance calling a consultative referendum on the accession of the Republic of Slovenia to the European Union, UL 13/03.
} 
constitutional amendment inserting Art. 3.a into the text of the Constitution was adopted, and para. 2 of the new Art. 3.a laid down the rules for referendums on transfers of powers:

Before ratifying a treaty referred to in the preceding paragraph, the National Assembly may call a referendum. A proposal is passed in the referendum if a majority of voters who have cast valid votes vote in favour of the same. The National Assembly is bound by the result of such referendum. If such referendum has been held, a referendum regarding the statute on the ratification of the treaty concerned may not be called.

The constitutional act also provided that the EU and NATO referendums shall be considered to fall under Art. 3.a. ${ }^{46}$ The popular vote was thus linked to the EU amendments, albeit in a peculiar manner.

The haste with which the referendum was coupled with the constitutional reform seems to have been behind the questionable decision for an 'abstract approach' to the phrasing of Art. 3.a. Applying Art. 3.a to the March 2003 referendums first and foremost meant that the result was legally binding on the National Assembly. As far as future referendums are concerned, it is important to note that an Art 3.a referendum is not obligatory. Whether such referendum will be called or not lies within the discretion of the National Assembly.

Igor Kaučič has warned that, strictly speaking, the object of an Art. 3.a referendum is not the treaty in question nor the statute ratifying the treaty, but an individual question that is of crucial or central importance to the treaty. ${ }^{47}$ In 2003 , the voters voted on whether they were in favour of Slovenia becoming a member of the European Union. This approach put into question the 'usefulness' of an Art. 3.a referendum for future reforms of the European Union, where it might be more difficult to identify the central question of the treaty. The relevance of a referendum where the electorate decides on a narrow point addressed by the treaty in question is likewise questionable. This inevitably raises the question whether the Art 3.a referendum was at all conceived as a functional tool of direct democracy in the processes of supranational integration or rather as an una tantum event based on an abstractly worded constitutional basis.

\subsection{The Reasons for, and the Role of, EU Amendments}

1.5.1 The 2003 reform The decision for a constitutional reform was based predominantly on the scholarly opinion that without such reform, accession to the EU would be unconstitutional. However, it seems that the influence of scholars was much more limited when it came to the shaping of the amendments. It seems that in the desire to provide additional, 'constitutional' legitimacy and weight to the

\footnotetext{
${ }^{46}$ Sect. II, Constitutional Act amending Chapter 1 and Arts. 47 and 68 of the Constitution of the Republic of Slovenia, UL 24/03.

${ }^{47}$ Kaučič 2011a, p. 85.
} 
referendum, politicians were ready to settle for a suboptimal phrasing of Art. 3.a, sacrificing a lengthier and more profound debate. This settling and sacrifice seem to have been unnecessary in relation to the process of joining the EU. The $89.64 \%$ vote in favour of joining the Union reflects the wide support that European integration enjoyed among the electorate. As far as the European Union was concerned, engaging in legal engineering instead of a substantial debate seems to have been uncalled for. It has to be taken into account, however, that the parallel process of joining NATO was much more controversial and might have lead the political elite to rig the rules of the game somewhat. ${ }^{48}$ In that sense, choosing an abstract, 'minimalist' approach to the constitutional reform and intentionally avoiding any explicit reference to the EU or NATO might have served the additional purpose of 'pooling' the legitimacy of both integration processes in order to ensure a smooth entry into both organisations. It seems that the whole process would have been more democratically and intellectually honest if the Constitution had, in the words of Confucius, 'called things by their proper name'.

This is not, however, to dismiss the explanations for the choice of the 'abstract' model provided by Slovenian scholars. In particular, the argument was put forth that the abstract model is compatible with the standard practice of constitutional drafting, which often opts for laconic phrases, combining them with a rule that prescribes that a statute is required to regulate the matter further. ${ }^{49}$ From my personal experience in observing and participating in the drafting of constitutional amendments (albeit not the EU-related ones), the prominent constitutionalists indeed seem to have a certain sense of what kind of wording is appropriate in the text of the Constitution. This indefinable aesthetics of constitution-making is probably a result of practice or custom and connected to the otherwise frequently cited belief that constitutional amendments are to be written 'with a trembling hand', i.e. with great caution and reserve. The laconic, 'aesthetic' approach might well partly be behind the division of the matter of the fiscal rule between constitutional and statutory text, discussed in Sect. 1.2.1. ${ }^{50}$

Regarding some of the other matters covered by EU amendments in other Member States, a possible explanation for why Slovenia has not enacted similar clauses is that the Constitution in its original text was to a certain extent already one of 'open statehood'. It is worth noting, for example, that the original text of the Constitution (1991) foresaw the possibility for a statute to grant electoral votes to foreigners, and the legislature indeed did so even before Slovenia joined the EU. ${ }^{51}$

\footnotetext{
48 Traynor, I. (2003, March 22). Slovenia split in run-up to Nato referendum. The Guardian. http:// www.theguardian.com/world/2003/mar/22/iantraynor.

49 E.g. Art. 12.

50 The other possible reason would be strategic: by 'throwing a bone', i.e. introducing the constitutional reform, the country probably assuaged the financial markets and bought time before more invasive measures were taken with the adoption of the fiscal rule statute.

51 The active right of permanently resident foreigners to vote in the indirect elections to the National Council, the upper chamber of Parliament, was recognised in 1992. Article 2 National Council Act; however, the right to vote in local elections dates back to 2002, before accession.
} 
The 2013 reform of Art. 148 The introduction of the fiscal rule was not uncontested. First, opinions diverged on whether the treaty required Slovenia to change the constitutional text. ${ }^{52}$ Secondly, Slovenian constitutional scholars felt that there was no room for a strong expression of ideology or one particular economic doctrine in the constitution. Constitutionalisation represents a long-term commitment that would require considerable effort to be overturned in the future, when the economic reality or policy may change. ${ }^{53}$ Additionally, the reasonableness of pursuing the European project by imposing a top-down constitutional reform on the Member States was questioned. ${ }^{54}$ It has also been pointed out that tension between debt limitations and the concept of the social state is inevitable, with calls made for the priority of the latter as a fundamental value of the Constitution. ${ }^{55}$

1.5.2 Not applicable.

1.5.3 The national constitution remains a powerful tool in the hands of the citizenry of a Member State whenever concerns arise that the power to make decisions on issues that affect them might shift from the democratic organs of the Member State to more distant centres, or simply wither away, with the hands of the elected politicians tied, as was the case with the Fiscal Compact (see above Sects. 1.2.1 and 1.5.1). The eurozone crisis has shown how quickly the Member States positioned the newly established rules and mechanisms (European Stability Mechanism; the Banking Union) in the grey postnational zone of Ersatzunionsrecht rather than within EU law. ${ }^{56}$ A strong case can be made for the requirement that such treaties must be submitted to a regime similar to the Art. 3.a regime (heightened ratification threshold, and substantive requirements for respect for human rights, pravna država and democracy). However, given the wording of Art. 3.a., it is likely that they would fall outside its scope of application. In a potential future constitutional reform, especially one that would introduce a clause calling Europe by its proper name (see above Sect. 1.5.1), I would support combining the latter with a more broadly applicable provision. Such a clause would be capable of submitting a range of different mechanisms of global and regional governance to the requirement of respect for the fundamental values of the Constitution.

\footnotetext{
52 On this debate, see Ahtik et al. 2014, p. 530.

${ }^{53}$ Bugarič 2012, p. 3; Vuksanović 2011, pp. 41- 42.

${ }^{54}$ Nahtigal 2012, p. 22.

${ }^{55}$ Nahtigal 2012, p. 22; Strban 2012, p. 3.

${ }^{56}$ Federal Constitutional Court of Germany, 2 BvR 1390/12, Judgment of 12 September 2012, para. 153; Bardutzky and Fahey 2014, p. 343.
} 


\section{Constitutional Rights, the Rule of Law and EU Law}

\subsection{The Position of Constitutional Rights and the Rule of Law in the Constitution}

2.1.1 The Constitution, as one of its basic principles, establishes the duty of the state to protect human rights on its territory (Art. 5). It further provides for a comprehensive catalogue of human rights (Chap. II).

The initial provisions of the Chapter guarantee equality in the exercise of human rights (Art. 14(1)) and provide for structural rules on the exercise and limitation of human rights and fundamental freedoms (Art. 15(1-3)). Importantly, the non-enumeration clause (Art. 15(5)) opens the catalogue: no human right or fundamental freedom entrenched in a legal act that is in force in Slovenia may be restricted on the grounds that it is not recognised by the Constitution (see Sect. 3.2.2).

The Constitution guarantees judicial protection of human rights and fundamental freedoms and restitution of the consequences of human rights violations (Art. 15(4)). An individual alleging a human rights violation by an individual legal act (court judgment, administrative decision, etc.) can access the Constitutional Court via a constitutional complaint (modelled after the German Verfassungsbeschwerde) after other remedies have been exhausted (Art. 160).

The Constitution expressly prohibits the retroactive effect of statutes, regulations and other general acts, and lays down the only exception from this rule (Art. 155). ${ }^{57}$ Legal certainty, protection of legitimate expectations and, perhaps most notably, proportionality are considered elements of the principle of pravna država, entrenched in Art. 2 Constitution (see Sect. 2.1.3).

Pravna država is not considered a human right, so one cannot base a constitutional complaint to the Constitutional Court on an allegation that it has been violated. Nevertheless, Art. 2 can and does serve as a yardstick in the procedure for the review of constitutionality of legislation (and other general acts). This procedure can be abstract, triggered by a number of privileged and semi-privileged applicants, concrete (a preliminary ruling-like mechanism initiated by the iudex a quo) and, under certain conditions, also accessible to individuals aggrieved by the norm in question.

2.1.2 The Constitution distinguishes between defining the manner in which a human right is exercised (Art. 15(2)), on the one hand, and limiting a human right (Art. 15(3)) on the other.

A statute can define how a human right is to be exercised 'whenever the Constitution so provides or where this is necessary due to the particular nature of an individual right or freedom'. For example: '[e]very citizen has the right, in

\footnotetext{
57 'Only a statute may provide for retroactive effect of some of its provisions, if this is required in the public interest and under the condition that no acquired rights are infringed.' (Art. 155(2)).
} 
accordance with statute, to participate either directly or through elected representatives in the management of public affairs' (Art. 44 Constitution, emphasis added). ${ }^{58}$

On the other hand, human rights and fundamental freedoms can only be limited by the rights of others and in the cases that are provided by the Constitution. First, as for limitations based on the rights of others, the text of the Constitution does not explicitly state that such right must be a constitutional or human right; however, a limitation imposed on a human right is not likely to pass the proportionality test if it is grounded in a right of lower rank (e.g. statutory, contractual). ${ }^{59}$ Secondly, there can be a statutory reservation that limits a human right. For example, the right to free movement (which is to be distinguished from the right to personal freedom) can be limited by statute only when this is necessary to ensure the conduct of criminal procedure, to prevent the spread of a contagious disease, to protect public order or if this is required for the defence of the state (Art. 32). In addition, the Constitutional Court has recognised that human rights can be limited on a third ground: the public interest. ${ }^{60}$

It is difficult to distinguish between a statutory provision that regulates the exercise of a human right (a para. II case) and a limitation of a human right (a para. III case). The distinction is nevertheless important: a lower threshold will be applied to cases where the legislature has regulated the exercise of a human right: it will suffice to show that the legislative solutions are not arbitrary, irrational, etc. However, whenever there is a limitation on a human right, the legislation will be submitted to a proportionality test. ${ }^{61}$

2.1.3 The Constitution (Art. 2) declares Slovenia to be a pravna država, a concept that can be considered equivalent to the German Rechtsstaat. The Slovenian term almost literally translates into (or from) the German equivalent; it is customarily translated into English as 'state governed by the rule of law'. Scholarship considers pravna država, democracy (Art. 1) and the social (welfare) state (socialna država; Art. 2) to be fundamental general constitutional principles. ${ }^{62}$

The discussion of the contents of this principle in the only commentary of the Constitution mostly draws on German commentaries of the Grundgesetz (Maunz/ Duerig). ${ }^{63}$ The majority of what is traditionally considered to be safeguarded by the principle of Rechtsstaat is entrenched expressis verbis in several provisions of the Slovenian Constitution: the principle of separation of powers (Art. 3), limitations on restrictions of human rights (Art. 15, see Sect. 2.1.2), the binding of the executive to statutory legislation (Art. 120(2)), the hierarchy of legal acts (Art. 153), the

\footnotetext{
${ }^{58}$ CCRS U-I-47/94, OdIUS IV, 4, para. 2; Avbelj 2011, p. 732.

${ }^{59}$ Testen 2002a, p. 198.

${ }^{60}$ Ibid., p. 200.

${ }^{61}$ Ibid., p. 196.

62 Šturm 2002, p. 53. Brkan and Nendl 2012 accord pravna država a pivotal role in the constitutional order.

${ }^{63}$ Šturm 2002, p. 54.
} 
prohibition of retroactive effect (Art. 155), the obligation to publish legal norms (Art. 154), the right to appeal and judicial review (Art. 25), the right to a constitutional complaint (Art. 160, see supra) and a system of procedural guarantees across the different procedures conducted by organs of public power (Arts. 17-31).

There are, however, three essential elements of pravna država not expressly codified in the text of the Constitution, but which have instead been recognised as such by the Constitutional Court:

- the principle of proportionality; ${ }^{64}$

- the principle of the protection of trust in the law, which requires that legal regulation be stable and foreseeable, and sets a limit on the de facto retroactive effect of legal norms; ${ }^{65}$

- the principle of clarity and coherence of legal norms, which aims at determining legal relationships to a sufficient level of exactness to exclude the arbitrariness of the organs of public power. ${ }^{66}$ Norms need to be clear and precise so that it possible to determine the meaning of the norms using the methods of legal interpretation. ${ }^{67}$ This principle also precludes the formulation of a norm in such a loose manner that the definition of the content of the norm would de facto lay in the hands of the authority enforcing the norm. ${ }^{68}$

In the context of this report, this becomes important when read together with the provisions of the Constitution that require that certain norms can only be adopted in the form of a statute (zakon). In addition to the rules mentioned above (only a statute can regulate the exercise of a human right and statutory reservations, etc.), the form of a statute is generally required whenever rights or duties are conferred on 'citizens and other persons' (Art. 87), in order to define criminal offences (nulla poena nullum crimen sine lege praevia - Art. 28) and in order for the state to 'impose taxes, customs duties, and other charges' (Art. 147).

The provision set out in Art. 87 accords the role of the 'essential legal acts' in the Slovenian legal system to statutes. ${ }^{69}$ Peter Pavlin has remarked that this is not merely true on the normative level; the statutes play this very role in the reality of the legal system as well. Sub-statutory, i.e. executive or other general legal acts can only regulate certain details regarding the exercise of a certain right or duty, and cannot hollow out or substitute its contents. 'Rights' in the sense of Art. 87 are not

\footnotetext{
${ }^{64}$ The principle of proportionality is also crucially linked to Art. 15(3), the provision on limitations on human rights and fundamental freedoms (see above Sect. 2.1.2). First, limitations on human rights and fundamental freedoms have to pass a proportionality test. Secondly, limitations are themselves limited, this also means that there are cases where the proportionality test cannot be used to justify a limitation (I am grateful to Andraž Zidar for this remark).

${ }^{65}$ See e.g. CCRS U-I-47/94, UL 13/95.

${ }^{66}$ See e.g. CCRS U-I-282/94, OdIUS IV, 108.

${ }^{67}$ CCRS U-I-32/00, UL 73/03.

${ }^{68}$ CCRS U-I-287/95, UL 68/96.

${ }^{69}$ CCRS U-I-40/96, OdIUS VI, 46.
} 
only human or constitutional rights, but all rights. ${ }^{70}$ It should be added that the impact of the use of the zakon as a legal form goes beyond the democratic legitimacy bestowed through the deliberations and vote in the directly elected National Assembly. Before a zakon comes into force, it is also exposed to potential further verification through a possible veto in the National Council and a legislative referendum that can be demanded by 40,000 voters. After a zakon has entered into force, however, it enjoys a privileged position in the legal system: courts of law are only bound by the Constitution and statutes (Art. 125 Constitution). They can refuse to apply a sub-statutory act that is not in conformity with the Constitution or the statutes (exceptio illegalis).

Pravna država and the derived or related principles are widely applied in the review of constitutionality and are the basis of extensive Constitutional Court case law.

In addition to the field of constitutional law, pravna država plays an important political role. The recent economic crisis (2009-ongoing) has caused a strong sentiment in society that the legal system was unable both to prevent and later to penalise the actions that damaged the economic system (politically sanctioned toxic loans issued by state-owned banks in order to finance managerial takeovers, acts of corruption and cartel agreements in large public tenders, etc.). Consequently, the public has criticised what it perceives as 'inefficiency' or even a 'lack' of rule of law, and expects that the legal system, in simplified terms, will ensure that the innocent walk, but even more that the guilty end up serving time. Given this atmosphere, it is not surprising that the winning party in the 2014 parliamentary election had stated that pravna država was its primary value and objective. The increased use of this notion in political discourse has probably already led to its diverging, multi-layered meanings. In the future, the challenge may lie in retaining the relevance and awareness of the core ideas of pravna država that are essential for the protection of the individual from excessive use of public power.

\subsection{The Balancing of Fundamental Rights and Economic Freedoms in EU Law}

2.2.1 There is no available evidence that the courts have transformed the optic or adjusted the balancing approach in a way that would favour economic freedoms over human rights. However, this could simply be due to the relatively limited engagement with EU law in Slovenian courts. ${ }^{71}$

In a contribution by Katarina Kresal Šoltes, a labour law scholar, the national constitution was explicitly positioned as relevant for the Viking and Laval

\footnotetext{
${ }^{70}$ Pavlin 2011, pp. 1154-1155.

${ }^{71}$ See Sect. 2.8.1.
} 
controversy. The importance of the right (autonomy) of collective industrial negotiation was underlined, and it was emphasised that despite the status that the economic freedoms have been accorded in ECJ case law, they cannot trump fundamental rights, especially the right to collective industrial action that is entrenched in a range of international documents. ${ }^{72}$ Kresal Šoltes also claims a (national) constitutional status for the right to autonomous collective negotiation, derived from the provisions of Art. 76 Constitution, ${ }^{73}$ and warns that the Constitution limits the limitations on human rights and fundamental freedoms (Art. 15(3), see Sect. 2.12). Kresal Šoltes has called for an interpretation of the 'free market and competition rules of EC law' that would - regardless of the Viking and Laval case law - refrain from limiting the right to collective industrial negotiation beyond the extent permitted under the constitutional traditions of the Member States. ${ }^{74}$ Worth noting is also the perspective of Damjan Kukovec, who discusses the Viking and Laval controversy by openly describing himself as a legal scholar from a periphery Member State (i.e. Slovenia). In his view, the typical framing of the Viking and Laval discussion, i.e. freedom of movement versus right to collective industrial action, overlooks the centre-periphery dynamics of European integration. ${ }^{75}$

\subsection{Constitutional Rights, the European Arrest Warrant and EU Criminal Law}

Introductory remark There are several clauses of the Slovenian Constitution that set limits on the power of the state in investigating and prosecuting crimes. Compared to international human rights documents, these provisions can be considered quite detailed: even some time limits are laid down by the Constitution itself. By way of illustration, a narrow selection of directly relevant articles - Art. 19 (Protection of Personal Liberty), Art. 20 (Orders for and Duration of Detention), Art. 23 (Right to Judicial Protection), Art. 25 (Right to Legal Remedies), Art. 27 (Presumption of Innocence), Art. 28 ((Principle of Legality in Criminal Law) and Art. 29 (Legal Guarantees in Criminal Proceedings) - contain almost 600 words (in their English translation). The text of these provisions has been partly provided in the footnotes in Sect. 2.3.

\footnotetext{
${ }^{72}$ Kresal Šoltes 2009.

73 'The freedom to establish, operate, and join trade unions shall be guaranteed.'

${ }^{74}$ Kresal Šoltes 2009, p. 485.

${ }^{75}$ Kukovec 2014.
} 


\subsubsection{The Presumption of Innocence}

2.3.1.1 The European Arrest Warrant (EAW) has not been contested based on the presumption of innocence. ${ }^{76}$ This can possibly be traced back to the phrasing of the relevant constitutional provision. ${ }^{77}$ In light of the Constitutional Court's case law, it is doubtful whether Art. 27 could be perceived as an argument against a measure such as the EAW. The Court does not consider the presumption of innocence to be an obstacle to the judicial detention of a criminal defendant ordered on the basis of the probability that the person in question might repeat the criminal act (Art. 201(1) (3) ZKP). The presumption of innocence is related to criminal guilt (nullum poena sine culpa $)^{78}$ and the key consequences derived from this presumption are closely linked to the establishment of criminal guilt: the onus probandi is on the state rather than on the defendant. Moreover, the risk of failing to prove the case is borne by the state, as the defendant is protected by the principle of in dubio pro reo. ${ }^{79}$

2.3.1.2 A person who is to be surrendered to another Member State on the basis of an EAW has to first be brought before an investigating judge. The scope of the judicial review before surrender, in a nutshell, is the following: the judge will instruct the person with regard to his or her rights, the contents of the warrant and the possibility of consenting to surrender (Arts. 19-22 ZSDČEUKZ-1). If the person does not consent to surrender, the judge will hear the testimony of the person to determine whether there are statutory reasons for refusal to surrender (Art. 23). ${ }^{80}$

The only information on refusals of EAWs by the courts is available from a study by the Institute of Criminology, which looked at all 58 warrants received in the first three years (2004-2007) after the entry into force of the European Arrest

\footnotetext{
${ }^{76}$ The author is grateful to Mojca Plesničar for confirming that this argument did not appear in the qualitative study that was based on a number of interviews with practitioners and policy-makers. See Šugman Stubbs and Plesničar 2009, pp. 501-522.

77 Article 27 Constitution: 'Any person charged with criminal conduct shall be presumed innocent until found guilty by a final judgment.' Zupančič positions the Slovenian constitutional provision between the broader guarantee of the French Declaration on the Rights of Man and of the Citizen of 1789 on the one hand and the narrower phrasing of Art. 6 ECHR, lamenting that the thus phrased provision is 'no longer a broad ethical postulate, but is rather limited to the context of criminal law'. Zupančič 2002, p. 302.

${ }^{78}$ Bele 2011, p. 412.

${ }^{79}$ CCRS U-I-18-93, UL 25/96, para. 67. We must note the institutional consequences of this understanding of the presumption of innocence. By unloading the burden and the risk of probation onto the 'state', it distinguishes the state in principal terms from the independent judiciary (Zupančič 2002, p. 303). This, in turn, requires that there is a prosecutor, an attorney of the state, who will pursue the state's case in an adversary manner.

${ }^{80}$ See also Šugman Stubbs 2008. It is in practice commonly considered the duty of the person to be surrendered to invoke grounds for refusal rather than this being an ex officio task of the court. Šugman Stubbs and Plesničar 2009, pp. 506-507.
} 
Warrant Act (hereinafter ZENPP). ${ }^{81}$ Five of these warrants were rejected: three cases involved Slovenian citizens where the offence was committed on Slovenian territory, one was rejected due to amnesty/pardon and one warrant was rejected because the requesting authority failed to provide assurances. ${ }^{82}$ It seems that at least in the first years of the operation of the system, there were no refusals to execute an EAW based on concerns related to the presumption of innocence.

\subsubsection{Nullum crimen, nulla poena sine lege}

2.3.2.1 The principle of nullum crimen sine lege praevia is expressly entrenched in Art. 28 Constitution as the 'principle of legality in criminal law'. ${ }^{83}$ This article lays down a further formal requirement by referring to a statute (zakon); indeed, the provision set out in Art. 28 has been linked to Art. 87 Constitution by commentators (see above Sect. 2.1.3 on Art. 87). ${ }^{84}$ Also, the Constitutional Court has found that the requirement that a statute defining a criminal offence be clear and precise (nullum crimen nulla poena sine lege certa) derives from the text of Art. $28 .^{85}$

Mojca M. Plesničar and Katja Šugman Stubbs have warned that the significant differences between the Member States' penal laws and the definitions of individual offences in the different systems can lead to a number of difficulties and to violation of the principle of legality as the fundamental principle of criminal law. The Slovenian lawyers who participated in the process of implementing mutual recognition, interviewed by Plesničar and Šugman Stubbs, assessed that the EU's plunge into mutual recognition in the field of criminal law was too hasty, but at the same time they felt that it was too late for a renegotiation through which the review of double criminality could be reinstated. As an alternative, it was suggested that each Member State could compile a list of offences (criminalised under its own penal law) that belong to the categories set out in Art. 2 of the EAW Framework Decision $^{86}$ (EAWFD). In addition to this 'positive list', Member States could enact a 'negative list' which would enumerate the offences under penal law that definitely

\footnotetext{
${ }^{81}$ UL 37/04. ZENPP was substituted by the Cooperation in Criminal Matters with the Member States of the European Union Act in 2008 (ZSKZDČEU; UL 102/07). A new act (ZSKZDČEU-1) was adopted in 2013.

82 Šugman Stubbs and Gorkič 2008, Sect. 11.4.2.e.

83 '(1) No one may be punished for an act which had not been declared a criminal offence under statute or for which a penalty had not been prescribed at the time the act was performed. (2) Acts that are criminal shall be established and the resulting penalties pronounced according to the statute that was in force at the time the act was performed, except where a more recent statute adopted is more lenient towards the offender.'

${ }^{84}$ Zupančič 2002, p. 312 citing the dissenting opinion of Judge Zupančič, joined by Judges Šturm and Sinkovec, to the CCRS decision Up-40/94 (OdIUS IV, 136).

85 CCRS U-I-247/96, UL 70/98, para. 11; Zupančič 2002, p. 313.

${ }^{86}$ Council Framework Decision of 13 June 2002 on the European arrest warrant and the surrender procedures between Member States (2002/584/JHA), [2002] OJ L 190/1.
} 
do not fall within the EAWFD categories. This latter solution, however, was found to be more difficult to implement in practice. ${ }^{87}$

\subsubsection{Fair Trial and In Absentia Judgments}

2.3.3.1 In the Slovenian context, the issue of the right to a fair trial and the EAW was raised by the failed challenge of Zoran Matešič, whose surrender was requested by an Italian court, against the ZENPP before the Constitutional Court. ${ }^{88}$ The constitutional concerns were also presented by Mr. Matešič's attorney in a periodical for legal professionals, and thus became more visible to academics and practitioners. $^{89}$

The case did not raise issues relating to in absentia trials, but rather addressed the right to a fair trial more generally. First, the challenge invoked the Art. 23(1) right to judicial protection, which not only guarantees everyone a formal appearance before a court, but also that the competent court will substantively review the matter at hand. ${ }^{90}$ However, by limiting the court to a review of purely formal non-execution grounds, the EAW procedures prevent the judiciary from providing any substantive judicial protection. Similarly, this can be seen as a violation of the Art. 25 right to a legal remedy: ${ }^{91}$ the Higher Courts that review the orders issued by the first instance panels do not exercise any substantive second instance control. Thirdly, the criminal procedural guarantees set out in Art. 29 Constitution, entrenching everyone's right to a fair trial and more precisely the right of a person 'to present all evidence to his benefit' are ignored. ${ }^{92}$ The requested person de facto has no possibility to present evidence and if he did, it would be to no avail: even if

\footnotetext{
87 Šugman Stubbs and Plesničar 2009, p. 207; Šugman Stubbs and Gorkič 2009a, p. 262; Šugman Stubbs and Plesničar 2009, p. 505.

${ }^{88}$ CCRS U-I-14/06, order of 22 June 2006, not reported. Šugman Stubbs and Plesničar 2009, pp. 516-517.

${ }^{89}$ Kovačič Mlinar 2006a, p. 13.

90 Article 23 (Right to Judicial Protection):

'(1) Everyone has the right to have any decision regarding his rights, duties, and any charges brought against him made without undue delay by an independent, impartial court constituted by statute.

(2) Only a judge duly appointed pursuant to rules previously established by statute and by judicial regulations may judge such an individual.'

91 'Everyone shall be guaranteed the right to appeal or to any other legal remedy against the decisions of courts and other state authorities, local community authorities, and bearers of public authority by which his rights, duties, or legal interests are determined.'

92 Article 29 (Legal Guarantees in Criminal Proceedings): 'Anyone charged with a criminal offence must, in addition to absolute equality, be guaranteed the following rights:

the right to have adequate time and facilities to prepare his defence;

the right to be present at his trial and to conduct his own defence or to be defended by a legal representative;

the right to present all evidence to his benefit;

the right not to incriminate himself or his relatives or those close to him, or to admit guilt.'
} 
the person were able to present convincing evidence that would disprove probable cause or refute the claims made against him or her in the requesting state, this would not have any impact whatsoever on the outcome of the judicial proceeding in the Slovenian court. ${ }^{93}$

The challenge against the ZENPP was submitted to the Constitutional Court while the EAW procedure was still pending before the first instance court, together with a motion for interim relief. However, the Constitutional Court refused to grant interim relief. As a result, immediately after the second instance criminal court had confirmed the decision to surrender Mr. Matešič, he was surrendered to Italy by the police. Having been surrendered, he lost legal standing in the procedure before the Constitutional Court, and his challenge was dismissed on procedural grounds. The decision was ascribed to the Constitutional Court lacking the courage to take an active position on the protection of human rights in the context of EU law. ${ }^{94}$

\subsubsection{The Right to a Fair Trial - Practical Challenges Regarding a Trial Abroad}

2.3.4.1 Šugman Stubbs and Plesničar interviewed a Slovenian defence attorney who often represents persons requested under an EAW. The following is their summary of the lawyer's experience with requested persons, who are usually

completely ignorant of the proceedings on EAW and expect that the hearing will give them a chance to prove their innocence. When faced with what seems to be merely an identification process they feel lost and bewildered. They are assigned a defence lawyer but usually are unable to communicate with him/her directly because of the language barriers between them. To requested persons, the entire process seems depersonalised and confusing, since they are usually unfamiliar with the system of surrender based on EAW, with the system in the executing State and very frequently with the system in the issuing country. ${ }^{95}$

To my knowledge, there is no assistance available to persons surrendered on the basis of an EAW after surrender. ${ }^{96}$ In discussing the burdens upon surrendered persons, three points should be made.

First, the burden of transportation to another country and undergoing a criminal trial there should in any case be made conditional upon a suitable standard of proof.

\footnotetext{
${ }^{93}$ Kovačič Mlinar 2006a p. 13.

${ }^{94}$ Kovačič Mlinar 2006b, p. 15; Erbežnik 2008, II-VII.

95 Šugman Stubbs and Plesničar 2009, pp. 520-521.

${ }^{96}$ Article 11(2) EAWFD was from the beginning implemented in such a way that a person who is subject to an EAW has to be represented by a criminal defence attorney from the moment the person is brought before the investigating judge up to the actual surrender, with the attorney appointed ex officio if the person does not appoint one himself (Art. 15(4) ZENPP, Art. 16(1) ZSKZDČEU, Art. 17(1) ZSKZDČEU-1). Hence, while the legislature has recognised the need for legal counsel and representation in EAW procedures, it has confined this assistance to the territory under its jurisdiction.
} 
According to the Slovenian Constitution, a judge may only order the detention of a person who can be reasonably suspected of having committed a crime (Art. 20 Constitution; emphasis added). ${ }^{97}$ I see no compelling reason to adopt a lower standard for judges to detain and surrender persons under an EAW.

Secondly, in cases such as Symeou, where the person was surrendered on the basis of an EAW to face inhuman detention conditions, true concern for human rights protection in Europe does not limit itself to fear for the wellbeing of the fellow nationals of one's own Member State upon potential surrender to another Member State. ${ }^{98}$ A finding that persons who are detained in a certain Member State suffer undue hardship should lead us not only to contest the system of judicial co-operation but the systemic violations of human rights in that Member State as well.

Thirdly, the potential for better ensuring the effective protection of the human rights of surrendered persons lies in involving a wide array of actors and institutions, from NGOs and defence lawyers to institutions on the national and European level, including ombudspersons. Traditionally, consular authorities are one of the initial points of assistance and information for a non-national facing a foreign repressive system. Despite the protection of this right being provided for in EU law (Art. 7 Directive 2013/48/EU ${ }^{99}$ ), this unfortunately remains to a great extent dependent on the facilities and capabilities of the Member State. Slovenia, for example, has never had representations in all of the EU Member States, and has recently even closed some of its existing representations due to cuts in public spending. While this has happened in a number of countries, we cannot escape the fact that it is comparatively much more burdensome for smaller countries to

${ }^{97}$ Article 20 (Orders for and Duration of Detention):

'(1) A person reasonably suspected of having committed a criminal offence may be detained only on the basis of a court order when this is absolutely necessary for the course of criminal proceedings or for reasons of public safety. (2) Upon detention, but no later than twenty-four hours thereafter, the person detained must be handed the written court order with a statement of reasons. The person detained has the right to appeal against the court order ....'

It should be noted that the Constitution safeguards personal liberty also in a more general (in scope) yet nevertheless detailed provision of Art. 19 (Protection of Personal Liberty):

'(1) Everyone has the right to personal liberty.

(2) No one may be deprived of his liberty except in such cases and pursuant to such procedures as are provided by law.

(3) Anyone deprived of his liberty must be immediately informed in his mother tongue, or in a language which he understands, of the reasons for being deprived of his liberty. Within the shortest possible time thereafter, he must also be informed in writing of why he has been deprived of his liberty. He must be instructed immediately that he is not obliged to make any statement, that he has the right to immediate legal representation of his own free choice and that the competent authority must, on his request, notify his relatives or those close to him of the deprivation of his liberty.'

${ }^{98}$ I am grateful to Monica Claes for this remark.

${ }^{99}$ Directive 2013/48/EU of the European Parliament and of the Council of 22 October 2013 on the right of access to a lawyer in criminal proceedings and in European arrest warrant proceedings, and on the right to have a third party informed upon deprivation of liberty and to communicate with third persons and with consular authorities while deprived of liberty, [2013] OJ L 294/1. 
maintain a diplomatic and consular presence abroad. This becomes compounded, as smaller countries tend to first close their representations in other small countries. ${ }^{100}$

2.3.4.2 To my knowledge, data on subsequent acquittals is not collected. A case could, however, be made for the collection and processing of a similar data set, as even some Slovenian judges feel that having knowledge of the outcome of the procedure that follows after a person has been surrendered would gradually deepen mutual trust between the judiciaries. ${ }^{101}$

\subsubsection{The Right to Effective Judicial Protection: The Principle of Mutual Recognition in EU Criminal Law and Abolition of the Exequatur in Civil and Commercial Matters}

\subsubsection{See Sect. 2.3.3.1.}

2.3.5.2 In his critique of mutual recognition in EU criminal law, Anže Erbežnik has warned that while Cassis de Dijon-style mutual recognition under the former first pillar has served to enhance European citizens' freedoms in the common market, transplanting this principle to criminal law without the prior substantial harmonisation of defence rights has mostly benefitted state authorities. ${ }^{102}$ The experts interviewed by Šugman Stubbs and Plesničar similarly found that former first-pillar EU law typically does not involve such subtle balances between the rights of the state and the rights of individuals. ${ }^{103}$ This is aggravated by the fact that in the former third pillar, this principle was introduced as an intergovernmental project, in absence of a democratic debate. ${ }^{104}$

2.3.5.3 Scholarship has warned that the 'uncritical application of the principle of mutual recognition bears the danger of transforming the judge into a kind of a "ticking box" automaton checking only pre-established criteria and neglecting his/ her duty of a critical assessment and safeguarding fundamental (constitutional) rights to the defendant'. This argument is grounded in the principle of separation of powers. ${ }^{105}$ Zvonko Fišer has found the ZENPP to instrumentalise the judge. ${ }^{106}$ In similar vein, the interpretation of the provision abolishing the dual criminality check for the 32 categories of offences, which was favoured by the European Commission and according to which the judge in the executing state is barred from

\footnotetext{
${ }^{100}$ Unfortunately, this observation goes hand in hand with Albi's concern that there are no proactive NGOs that would monitor such cases in smaller Member States. Albi 2015, p. 171.

101 Šugman Stubbs and Plesničar 2009, p. 520.

102 Erbežnik 2014a, pp. 138-139; citing Möstl 2010; Mitsilegas 2006.

103 Šugman Stubbs and Plesničar 2009.

${ }^{104}$ Erbežnik 2014a, pp. 138-139.

105 Erbežnik 2014a, p. 131.

${ }^{106}$ Fišer 2008, Sect. 3.4. Fišer currently serves as State Prosecutor General.
} 
checking prima facie whether the legal qualification put forward by the requesting state is correct or even sensible, has been considered as insulting to the judicial function. ${ }^{107}$ More generally, reducing the scope of judicial review has been considered to also reduce 'the awareness that it is for the judiciary to observe and to enforce procedural safeguards as guaranteed by national constitutional orders, thus preserving the delicate balance between the individual and the state ... [certainly,] the balance has shifted'. ${ }^{108}$

2.3.5.4 In my view, it is a fundamental premise of the exercise of public power that interference with the rights and freedoms of the individual must be in proportion with the legitimate interests pursued. The image of a judge whose intellectual activity has been reduced to ticking boxes and who has been purged of the constitutional constraints that should be present at all times is incompatible with this fundamental premise (and with the guarantees of Art. 20 Constitution, see Sect. 2.3.4.1). Stories such as that of Neeme Laurits, ${ }^{109}$ for whom the execution of what proved to be a groundless EAW led to grave consequences for his private and family life, have to make us consider the guarantees provided by Art. 8 of the European Convention on Human Rights (ECHR) and analogous national constitutional provisions.

As an illustration of how the right of family life (Arts. 53, 54 and 56 Constitution) can soften the effect of the penal system in a situation where a person is to be separated from his environment and sent abroad, consider the Vizgirda decision of the Slovenian Constitutional Court. The case is not connected to the issues of mutual recognition and does not apply EU law. However, the complainant, a Lithuanian citizen, had been convicted in a Slovenian court and was to be expelled from the national territory. ${ }^{110}$ The Supreme Court had rejected Mr. Vizgirda's request for an extraordinary suspension of the expulsion sentence, in which he had pleaded that he had fathered a child - a Slovenian citizen, living in Slovenia. The Constitutional Court found that the penalty of expulsion served a legitimate goal of public safety. Nevertheless, in Mr. Vizgirda's case, it was not proportionate in light of the constitutional right to family life and the rights of the child. Relying on ECHR case law, the Constitutional Court stressed that the deeper the integration of the person concerned in the country in question, the higher the level of protection from expulsion must be. The state was under a duty to consider a range of circumstances before it adopted a final decision. ${ }^{111}$

The Vizgirda decision undoubtedly arose in a very different legal setting, which has to be taken into account when comparing it to EAW cases. Nevertheless, it demonstrates how constitutional judges are prepared to protect an individual's right to family life even in the face of compelling public interest. That, I would suggest,

\footnotetext{
107 Šugman Stubbs and Gorkič 2008, Sect. 9.1.2.

108 Šugman Stubbs and Gorkič 2009b, p. 242.

${ }^{109}$ Albi 2015, p. 171.

${ }^{110}$ Expulsion of a foreign national as a criminal sentence was abolished in 2008.

${ }^{111}$ CCRS Up-690/10, UL 42/2012.
} 
should be a serious argument when analysing the law and policy behind cases such as that of Mr. Laurits.

\subsubsection{Constitutional Rights Regarding Other Aspects of EU Criminal Law}

In Slovenia, the state prosecutor (državni tožilec) is perceived as one of the parties in criminal proceedings. This role is not quasi-judicial, as is the case in some other Member States. ${ }^{112}$ Erbežnik has warned that it is unsettling for a state such as Slovenia to sanction a direct execution per its judges of a decision taken by a state prosecutor in another Member State. The perception of the role of a prosecutor in a state is often historically rooted as an element of the state's legal culture and identity. Erbežnik fears that a possible spillover effect of the system of mutual recognition might be the obliteration of the differences in the perception of the role of the prosecutor in different Member States, and an overall trend towards the judicialisation of the prosecutor's role, with the prosecutor being armed with various powers over criminal suspects. ${ }^{113}$

Language seems to be an issue in the operation of systems based on mutual recognition. Smaller Member States can experience practical difficulties in arranging for the adequate translation of EAW requests, especially those issued by other small Member States, i.e. written in the less commonly spoken languages of the Union. ${ }^{114}$ In 2014, a police officer of the Ljubljana Schengen Compensatory Measures Unit wrote a very interesting short note defending the legal stance of the Police. The Police had refused to detain a Romanian citizen who was subjected to an EAW until a Romanian translator was found. ${ }^{115}$

\subsection{The EU Data Retention Directive}

2.4.1 A constitutional challenge against the Electronic Communications Act (ZEKom-1), ${ }^{116}$ the legislation implementing the Data Retention Directive, ${ }^{117}$ was

\footnotetext{
112 The Office of the State Prosecutor General is a constitutional institution (Arts. 135-136).

${ }^{113}$ Erbežnik 2010, p. 213; Erbežnik 2014a, pp. 141-143.

${ }^{114}$ EAW requests are also accepted by Slovenian authorities if they are issued or translated into English (Art. 6(6) ZSKZDČEU-1). The concerns raised by this rule among the Slovenian practitioners, in a country highly sensitive of its linguistic identity, were recorded by Šugman Stubbs and Plesničar 2009, p. 520. As the official languages of Slovenia are defined by the Constitution (Art. 11), the use of other languages in legal proceedings could present a constitutional issue.

115 Jurič 2014, pp. 8-10.

116 UL 109/12.

${ }^{117}$ Directive 2006/24/EC of the European Parliament and of the Council of 15 March 2006 on the retention of data generated or processed in connection with the provision of publicly available
} 
filed by the Information Commissioner in 2013. ${ }^{118}$ The claim of the Commissioner was that the retention of data on such a massive scale is a disproportionate limitation on freedom of movement (Art. 32 Constitution), the right to privacy (Art. 35), the right to privacy of correspondence and other means of communication (Art. 37) and the right to protection of personal data (Art. 38). The Commissioner also put forward a claim that the implementation of the directive was flawed, as the Slovenian legislature defined a broader set of legitimate objectives than provided in the text of the Directive.

The Information Commissioner underlined that data retention under ZEKom-1 effectively violated the freedom of movement as it enabled location tracking and, as such, was capable of providing a complete record of an individual's movements. In that sense it was comparable to a hypothetical general obligation to carry location tracking chips. Similarly, there were concerns regarding freedom of speech, as the control of communications on such a scale can be expected to lead to self-censorship by individuals communicating with one another. With billions of calls and messages recorded and only several hundred requests made to the processors every year, as few as $0.012 \%$ of the personal data retained is ever used in pursuit of the objectives for which data retention was introduced.

The Commissioner also warned of a function creep. In the course of inspecting communication providers, it was established that the providers were receiving requests unrelated to criminal investigations, but rather in connection to, for example, civil litigation or labour disputes. ${ }^{119}$

In September 2013, the Constitutional Court decided to stay the proceedings and wait for the outcome of the cases C-293/12 and C-594/12 in the ECJ. ${ }^{120}$ The decision to stay and wait was based on the finding that the Commissioner's claim was in effect that the Directive violated Arts. 7 and 8 of the Charter of Fundamental Rights. ${ }^{121}$ Hence, the Constitutional Court noted that 'the decision on the validity of the Directive is of key relevance to the review of constitutionality of national legislation'. ${ }^{122}$ The Court did not refer any questions for a preliminary ruling, as

\footnotetext{
electronic communications services or of public communications networks and amending Directive 2002/58/EC, [2006] OJ L 105/54.

${ }^{118}$ The Information Commissioner is an independent authority charged with the protection of personal data and access to documents. The Commissioner reviews decisions to deny access to public documents and refusals to disclose personal data. (Act on the Information Commissioner, UL 113/05 and 51/07). The Commissioner has standing before the Constitutional Court, when in a procedure conducted by the Commissioner, a question of the constitutionality of the legislation that the Commissioner has to apply is raised. (Art. 23.a ZUstS).

119 The request of the Information Commissioner is available (in Slovene) at https://www.ip-rs.si/ fileadmin/user_upload/Pdf/ocene_ustavnosti/ZEKom_-_Zahteva_za_oceno_ustavnosti__data_ retention_.pdf.

${ }^{120}$ The Court found that the ECJ decision in Case C-301/06 Ireland v. Council was 'with regard to the issue of legal basis only' (emphasis added). CCRS U-I-65/13, Order of 26 Sept 2013, para. 9.

${ }^{121}$ U-I-65/13, para. 5.

${ }^{122}$ Ibid., para. 8.
} 
similar proceedings were already in progress. ${ }^{123}$ In the resumed proceedings (after the ECJ judgment), the Court established that even after the annulment of the Directive, data retention remained a matter for EU law: Directive 2002/58/EC ${ }^{124}$ allows the Member States to adopt legislative measures encroaching on the confidentiality of data in transit, including data retention, when this is necessary, appropriate and adequate in a democratic society to serve a number of legitimate aims. The Constitutional Court found these requirements to correspond, in substance, to the requirement of proportionality that must be fulfilled in order for a limitation on a human right to be legal under Slovenian constitutional law. The Court annulled the contested provisions and ordered the processors to immediately destroy all retained data. While the Information Commissioner invoked several human rights provisions of the Constitution, the review by the Court was based on Art. 38(1), which focuses on the personal data aspect of the issue:

The protection of personal data shall be guaranteed. The use of personal data contrary to the purpose for which it was collected is prohibited. ${ }^{125}$

It is clear from this case that the annulment of a 'source' directive is not sufficient to remove the legal norms that implement it from the Slovenian legal system. It is, however, questionable whether the precious resources of the Constitutional Court are well allocated with the Court taking over this 'purification' function, which could be left to the legislature. A solution (that would admittedly probably require some dialogue among the branches of government) could be found where the Court would only resume the proceedings (in the interest of protecting the individuals aggrieved by the implementing measure) if the legislative and executive branches were dragging their feet after an ECJ annulment. This is far from saying that the Court should not engage with EU law that violates human rights; in fact, it is almost the opposite. Rather than waiting for the ECJ to deliver a judgment and then going through the mental exercise of checking the conformity of the implementing measure with the Constitution, feeding on the arguments of the ECJ, the Court should do the mental exercise at an earlier stage and incorporate the results of the mental exercise into a reference for a preliminary ruling.

\footnotetext{
${ }^{123}$ Bardutzky 2014b.

${ }^{124}$ Directive 2002/58/EC of the European Parliament and of the Council of 12 July 2002 concerning the processing of personal data and the protection of privacy in the electronic communications sector (Directive on privacy and electronic communications), [2002] OJ L 201/37.

125 The focus on Art. 38(1) is interesting in its own right, as the provisions of Art. 37 (Protection of the Privacy of Correspondence and Other Means of Communication) offer stricter guarantees:

'(1) The privacy of correspondence and other means of communication shall be guaranteed.

(2) Only a statute may prescribe that on the basis of a court order the protection of the privacy of correspondence and other means of communication and the inviolability of personal privacy be suspended for a set time where such is necessary for the institution or course of criminal proceedings or for reasons of national security.'
} 


\subsection{Unpublished or Secret Legislation}

2.5.1 It is almost completely unimaginable that unpublished or secret legislation could ever be compatible with the Slovenian constitutional order. The very concept evokes nightmarish flashbacks of the Communist Party controlled regime that was removed in 1990-1991 - inter alia by adopting the new Constitution. There were two types of secret legislation in the former Yugoslavia. First, in addition to the Official Gazette, there was also a secret official gazette that was made available to only between 22 and 40 authorised recipients. The federal secret official gazette was established in 1980, and in the following year, all six constituent republics started issuing their own secret official gazettes. The scope of secret legislation was broad and comparable to the scope of 'public' legislation. In addition to numerous executive and sub-statutory acts, as many as 55 statutes (i.e. acts of the legislature of general application) were published in the federal secret official gazette; often, economic and financial regulation was published in this way. Secondly, before and after the introduction of the secret official gazette, there were legal norms in use that were too classified even for 'secret publication'. These norms primarily dealt with state security. Based on this experience, the opinion was formed that secret legal norms are not legal norms at all; they merely pose as such and can never be part of the legal order. ${ }^{126}$ According to the Constitutional Court, the 'mere existence of secret norms that contained authorisations for the political police was tantamount to a gross violation of human rights and fundamental freedoms'. ${ }^{127}$

The Constitution states that all general and abstract legal acts (predpis) have to be published before they can enter into force. Legal acts of the state are to be published in the Official Gazette; legal acts of the local communities are to be published in gazettes chosen by the communities (Art. 154). The Constitutional Court has built its Art. 154 case law mostly upon developing a material conception of the predpis. The form of a legal act is less relevant for the question whether the act needs to be published; the essential questions are whether the text contains any general and abstract legal norms, whether it regulates a right or a duty and whether it creates external legal effects. ${ }^{128}$

\footnotetext{
126 Šturm 1998, pp. 285-287; Testen 2002b, p. 1033.

${ }^{127}$ CCRS U-I-25/95, UL 5/98, para. 84. The case echoed in Sadurski's account as follows: 'No doubt the evocation of this recent history, from before the collapse of Yugoslavia, added a powerful persuasive force to the court's hostility towards the use of such secretive means, even for the perfectly justifiable ends of fighting crime, particularly organised crime.' Sadurski 2005, p 147. 128 Šturm 2011, pp. 1363 et seq. In 1998, the Constitutional Court was seized with a challenge against a secret agreement between the defence ministries (or rather the military intelligence services) of Slovenia and Israel. The Court dismissed the challenge on procedural grounds given that there was no legal act whatsoever that the Court could review; however, obiter dicta, the Court made it clear that without complying with a proper procedure of ratification and publication, an agreement between two states cannot become part of the Slovenian legal order. CCRS U-I-128/98, Order of 23 September 1998, OdIUS VII, 173. See also Sect. 3.1.
} 


\subsection{Rights and General Principles of Law in the Context of Market Regulation: Property Rights, Legal Certainty, Non-retroactivity and Proportionality}

2.6.1 The first request for a preliminary ruling from the Constitutional Court expresses doubt as to the legality of the Commission's 'Banking Communication'. ${ }^{129}$ At the time of writing, the case was pending before the ECJ. ${ }^{130}$ A challenge was brought against the provisions of the Banking Act (ZBan-1) ${ }^{131}$ that were the legal basis for a bail-in operation, executed via decisions of the Bank of Slovenia and that affected the holders of bonds of five different Slovenian banks.

In response, the Government and the National Assembly argued that the contested provisions were adopted in order for Slovenia to comply with the requirements put forward by the European Commission in the Banking Communication. The only way that the Commission would find that the state aid given to the banks was legal was if Slovenia complied with the Banking Communication in advance. ${ }^{132}$ In effect, the enactment of the problematic provisions of the Banking Act was allegedly a 'transposition' of this, at least by name, soft law measure. The Constitutional Court has therefore first asked whether the Banking Communication, 'taking into account the legal effects that are de facto created' and given the exclusive competence of the European Union in state aid law, is to be interpreted as being binding for the Member States.

The Court has also asked for a preliminary ruling as to the validity of the Communication, to first determine whether it was within the boundaries of the Commission's competences. However, even if this should be the case, the Constitutional Court has its concerns with regard to the principle of protection of legitimate expectations and the right to private property.

According to the Court, legitimate expectations might be disrupted for the persons who held instruments of equity and debt that had been issued before the Banking Communication was issued. At the time of investing their assets, the affected persons did not know that in the future, state aid to banks would be made conditional upon negative changes to the instruments in their hands. With the exception of insolvency proceedings, there was no legal regime in existence that could lead to the deterioration or obliteration of their entitlements at the time when they chose to invest in the affected instruments. At the same time, the Court has recognised that there is an element of public interest in not limiting the temporal

\footnotetext{
${ }^{129}$ Communication from the Commission on the application, from 1 August 2013, of State aid rules to support measures in favour of banks in the context of the financial crisis ('Banking Communication'), [2013] OJ C 216/1; CCRS U-I-295/13, Order of 6 November 2014.

${ }^{130}$ Case C-526/14 Kotnik and Others [2006] ECLI:EU:C:2016:570.

${ }^{131}$ UL 99/10 etc., the provisions contested in U-I-295/13 were inserted by the ZBan-1L amendments (UL 96/13).

${ }^{132}$ CCRS U-I-295/13, Order of 6 November 2014, para. 10.
} 
scope of the Banking Communication. To do so would increase the strain on public finances and harm competition. ${ }^{133}$

There is no doubt that the measures required by the Banking Commission encroach upon the right to private property of the persons affected. The question thus is whether the encroachment is permissible under EU law. ${ }^{134}$ The Court doubts that the encroachment is proportionate, as it does not necessarily make it possible for the concrete circumstances in the individual Member States which could determine the proportionality of the encroachments to be taken into account.

The Constitutional Court has evoked ECHR case law on appropriate compensation for encroachments upon private property and questioned the proportionality of the erasure of the affected entitlements that is based only on an evaluation of the liquidation value of the bank, whereas the actual liquidation will never take place.

The Court is concerned that the persons affected by the Banking Communication measures will be excessively burdened with the costs of restructuring the bank. This is especially the case under the contested regime, as not all categories of stakeholders in the banks participate in the losses; on the contrary, depositors and senior bond holders only reap the benefits of the state aid that will subsequently be given to the bank in question. At the same time, the Court recognises that the Communication pertains to the stakeholders whose position has been more exposed to risk from the beginning. ${ }^{135}$

\subsection{The ESM Treaty, Austerity Programmes and the Democratic, Rule-of-Law-Based State}

2.7.1 The European Stability Mechanism (ESM) - or the participation of Slovenia therein - has not been challenged before the Constitutional Court. Given the substantial commitment undertaken by Slovenia upon participating in the ESM (the entire capital subscription amounts to almost one-third of the annual state budget), ${ }^{136}$ it is notable that the political debate was almost non-existent. The record of the discussion at the plenary session of the National Assembly in which the ratification statute was adopted is no longer than 1,121 words. The representatives of the largest governing party and the largest opposition party took the floor. For the former, the ESM Treaty was 'in the utmost interest of Slovenia', while according to

\footnotetext{
133 Ibid., para. 44.

${ }^{134}$ Ibid., para. 48.

135 Ibid., paras. 50-51.

${ }^{136}$ Slovenia's share in the total authorised capital stock of the ESM is $0.42 \%$, which amounts to 2.993 million EUR (ESM Treaty - consolidated version following Lithuania's accession to the ESM, Annex I). The State expenditure for 2015 is 9.485 million EUR (Budget of the Republic of Slovenia, UL 102/13, 14/15).
} 
the latter, 'any measure that strengthens the common currency is more than welcome'. ${ }^{137}$

2.7.2 While the ESM has not been contested in Slovenia, there was a constitutional challenge to one of its predecessors, the European Financial Stability Facility (EFSF). A group of 37 deputies of the National Assembly challenged the ZPZFSEu, the statute that provided the legal basis for the participation of Slovenia in the EFSF, before the Constitutional Court. ${ }^{138}$ The deputies claimed that the ZPZFSEu, in determining only the total sum and duration of Slovenia's guarantees for the EFSF's funding instruments, violated Art. 149 Constitution. ${ }^{139}$ The deputies asserted that the Constitution demands a special statute for each state guarantee, which lays down all the elements of the guarantee. Failure to provide such statute also amounts to a violation of the principle of separation of powers, as the role of the National Assembly is limited to being informed of any guarantees given. ${ }^{140}$

The Constitutional Court rejected all of the deputies' claims and found that the ZPZFSEu does not envisage a series of guarantees. It is the legal basis for one large scale guarantee, with withdrawals to be made gradually, over a longer period of time, and in proportion to what is required. ${ }^{141}$ In laying down the grounds for its ruling, the Court formulated some important positions. First, long term economic effects and their consequences for financial stability cannot be evaluated by looking at an individual measure, but rather require constant observation and continuous assessment. This, however, is not a task for the courts. It is for the Government and the Parliament to undertake and, in doing so, they are to enjoy a wide margin of appreciation. Hence, the judicial review of such questions has to be reserved. ${ }^{142}$

Secondly, even before the fiscal rule was introduced in the Constitution (see Sect. 1.2.1), the Court had found that Art. 149 Constitution cannot be interpreted as allowing the National Assembly to provide a carte blanche to the Government in matters of borrowing: the obligations undertaken must be, if not determined, at least determinable. This is regardless of the fact that Art. 149 does not set any material conditions or limitations for state borrowing or guarantees. The determinability of (future) obligations is required by the principle of pravna država and, not less

\footnotetext{
${ }^{137}$ Record of the plenary session of the National Assembly of 19 April 2012. However, Ahtik et al. 2014, p. 529 report on the calls of parliamentarians to be more fully involved in the Economic and Monetary Union governance.

${ }^{138}$ Act Regulating the Guarantees of the Republic of Slovenia for Ensuring Financial Stability in the Euro Area (UL 59/10, 79/11).

139 Art. 149: 'State borrowings and state guarantees for loans are permitted only on the basis of a statute.' See Bardutzky 2011, p. 1338.

${ }^{140}$ CCRS U-I-178/10, UL 12/2011, para. 1.

${ }^{141}$ Ibid., para. 29

142 Ibid., para. 9.
} 
importantly, the principle of the social (welfare) state (socialna država) that commands that

the State, in any given moment and also for future generations, which are to bear the burden of the debt incurred in the present, must provide the social minimum, that amounts not merely to the minimum required to survive, but ensures the possibilities to foster social relationships and to participate in social, cultural and political life. ${ }^{143}$

It is quite striking that the Court not only looked beyond the constitutional provisions that would conventionally be considered most narrowly related to the issue at hand, but it also invoked none other than the principle of socialna država. The latter traditionally stands for demands for solidarity within society and recognises the value of wide access to public services. It can potentially present a strong obstacle to a spectrum of different designs for Europe's economic constitution. In the hands of the Slovenian Constitutional Court, visibly influenced by the discourse prevalent in the German Federal Constitutional Court, it was deployed in order to establish an 'unwritten debt cap'. Meta Ahtik, Maja Brkan and Živa Nendl have thus justifiably wondered whether the Court has not taken 'a step too far in limiting the state's margin of manoeuvre for guaranteeing the respect for the value that the Court appears to hold at the heart of its reasoning'. ${ }^{144}$ Whether the Court's concern for the welfare state (of future generations) will consequently be employed in the future to further the ordoliberal ideals of prudent public spending, remains to be seen.

2.7.3 Perhaps the most commonly mentioned reason for the Slovenian economic crisis is the large influx of cheap capital between 2004 in $2008 .{ }^{145}$ This was cut short by the global financial crisis when lenders refused to extend loans which businesses were unable to repay, thus exposing the fact that the borrowing was excessive. The banking sector itself was not inflated (as was for example the case in Cyprus), ${ }^{146}$ but it was detrimental that the majority of it was state owned, as the losses of the banks immediately impacted state finances. ${ }^{147}$ State ownership of the banks and the resulting political influence over lending decisions led the banks to finance managerial takeovers of state-owned businesses in the real sector. This contributed to the sum of toxic loans in the banks' balances. In general, Slovenia stands out somewhat from the other post-socialist Member States of the European Union, as its process of privatisation of state-owned companies has been exceptionally slow and is in fact not yet finished. ${ }^{148}$ As a consequence, foreign direct investment in the country remains low.

\footnotetext{
143 Ibid., para. 25.

144 Ahtik et al. 2014, p. 535.

145 See for example Križanič 2012.

146 (2013, November 30). Slovenia's financial crisis: Stressed out. The Economist. http://www. economist.com/news/finance-and-economics/21590956-fight-avoid-sixth-euro-zone-bail-outreaches-climax-stressed-out.

147 Jazbec 2014.

${ }^{148}$ For an overview of the privatisation process in Slovenia until 2005, see Mencinger 2006.
} 
Slovenia has so far avoided having to ask for financial support and entering an externally imposed austerity programme. However, as there were severe difficulties with the state's public finances in recent years, Slovenia found itself in a situation where the bailout scenario appeared to be an inevitable reality. ${ }^{149}$ In my view, the general public was prevalently opposed to the possibility of a bail-out and, consequently, to any austerity programme designed by the EU and the IMF. This might be attributable to the fact that at the time Slovenia was facing this scenario, the public was already aware of the experiences of other countries that had gone down that road before, especially Greece. ${ }^{150}$ A scenario of external financial support was by and large considered undesirable by Slovenian lawyers and economists; ${ }^{151}$ however, this view was not unanimous. Avbelj discussed the possibility of the troika as a 'catalyst for democracy'. In his argument, the insolvency of a state is a reflection of its dysfunctional democratic process. The most persuasive out of a range of possible reasons for this dysfunction is that the system has been captured by smaller interest groups that prevent it from cleansing itself of bad rulers. If this were the case, the right to vote would become no more than illusory; once the state is totally captured, the only solution is an intervention from outside. This option harbours the potential to liberate the state from its captors, thus reinstating factual democracy. In reality, it is unlikely that the troika would wield sufficient power to truly prevent the interest groups from releasing their grip on the state. ${ }^{152}$

\footnotetext{
${ }^{149}$ Slovenia remains in an excessive deficit procedure (Regulation 473/2013) that has been ongoing since 2009 , and is considered to be experiencing excessive macroeconomic imbalances in the sense of Regulation 1176/2011.

${ }^{150}$ That the image of Greece and its experience was present even in the discussions of the judges of the Constitutional Court is revealed in the concurring opinion of Judge Petrič (a professor of international law) in U-II-1/12, U-II-2/12 (the decision is discussed above in Sect. 1.3.4): 'The position of Greece in relation to those, who de facto (albeit in the form of negotiations) determine the conditions of assistance and subsequently oversee the implementation of that agreement (including the parliaments of the other EU/Eurozone Member States), from a substantive point of view amounts to a limitation of Greece's sovereignty, even if the country - from a formal point of view of international law - remains a sovereign state.', para. 4.

${ }^{151}$ As an example, the opinion of Bogomir Kovač, Professor of Economics at the University of Ljubljana, that the reforms of economic governance have turned the EU into a tyranny, with the troika as the essence of European democracy rather than a deviation from it (Kovač, B. (2014, January 24) 1, 2, 3. Mladina.). See also Trampuš, J. (2013, October 10). Klicanje trojke (Calling the troika). Mladina, for a selection of views of politicians and other public figures on the consequences of possible entry into an austerity programme for Slovenia.
}

${ }^{152}$ Avbelj 2013a, b. 


\subsection{Judicial Review of EU Measures: Access to Justice and the Standard of Review}

2.8.1 Slovenian courts have not been very active in requesting preliminary rulings from the ECJ (nine requests altogether since the 2004 accession). ${ }^{153}$ The eight requests filed by the Supreme Court, the Administrative Court and the High Court of Maribor were all with regard to the interpretation of EU law. ${ }^{154}$ Only the request filed by the Constitutional Court (currently pending) regards the conformity of an EU soft law measure with superior EU law and legal principles (see Sect. 2.6.1).

2.8.2-2.8.3 The tables below indicate the intensity of judicial review before the Constitutional Court between 2009 and 2013. The data presented is with regard to the two most important types of procedure: the review of abstract legal norms, including parliamentary legislation, executive and local regulations, etc. (the 'U-I' docket), and constitutional complaints against individual legal acts (the 'Up' docket; see Sect. 2.1.1). In general terms, the Constitutional Court controls the regulatory activity of the legislative and executive branches and of the local governments in U-I cases. In Up cases, it oversees the compliance of the judiciary with human rights requirements.

In the observed period, between 7 and $15 \%$ of challenges against the different abstract legal norms were successful, as described in Table $1 .{ }^{155}$

With regard to constitutional complaints, it must first be noted that the Constitutional Court is seized every year with more than one thousand complaints, but only a tiny percent advance to the merit stage. ${ }^{156}$ Of the less than one hundred cases heard on the merits, a huge majority are successful. However, it is clear that many unfounded cases are dealt with in the admissibility stage. Therefore, in order to provide an accurate picture of the Constitutional Court's review of other

\footnotetext{
${ }^{153}$ Zagorc and Bardutzky 2010, p. 444.

154 The database of preliminary rulings requested by Slovenian courts other than the Constitutional Court is maintained by the Supreme Court and available at http://www.sodisce.si/znanje/sodna praksa/baza_seu/.

${ }^{155}$ The numbers in the table encompass all challenges regardless of the type of act that was challenged (parliamentary legislation, executive regulation, local act) and the type of applicant (state institution, private citizen or court by way of incidenter proceedings). Under 'successful challenges', I have counted all the cases where a norm was annulled or a situation of nonconformity with superior law was merely established. Under 'unsuccessful challenges', I have counted all cases where the Court has ruled that the measure is not contrary to superior law and the cases where a private citizen's claim was rejected, which occurs when a claim is either manifestly unfounded or does not address an important issue (Art. 26(2) ZUstS). Challenges are dismissed on procedural grounds mostly when the private citizen that filed a claim is not considered to be affected by the contested measure (pravni interes; Art. 24 ZUstS), but also when other procedural requirements are not fulfilled.

${ }^{156}$ Legislation enables the Court to weed out the complaints that neither bear grave consequences for the complainant nor lead to the resolution of an important question (Arts. 55-56 ZUstS).
} 
Table 1 Outcome of the review of legislation and other abstract legal norms

\begin{tabular}{l|l|l|l|l|l}
\hline Year & 2013 & 2012 & 2011 & 2010 & 2009 \\
\hline \multirow{2}{*}{ Successful challenges } & 26 & 31 & 49 & 25 & 32 \\
\cline { 2 - 6 } & $7.16 \%$ & $8.86 \%$ & $14.45 \%$ & $9.77 \%$ & $9.61 \%$ \\
\hline \multirow{2}{*}{ Unsuccessful challenges } & 77 & 50 & 76 & 42 & 68 \\
\cline { 2 - 6 } & $21.21 \%$ & $14.29 \%$ & $22.42 \%$ & $16.41 \%$ & $20.42 \%$ \\
\hline \multirow{2}{*}{$\begin{array}{l}\text { Challenges dismissed on procedural } \\
\text { grounds }\end{array}$} & 260 & 269 & 214 & 189 & 233 \\
\cline { 2 - 6 } & $71.63 \%$ & $76.86 \%$ & $63.13 \%$ & $73.83 \%$ & $69.97 \%$ \\
\hline Total & 363 & 350 & 339 & 256 & 333 \\
\hline
\end{tabular}

Source Annual Report of the Constitutional Court (2013)

The figures are from the Annual Report of the Constitutional Court (2013), p. 77, http://www.usrs.si/media/rsus_porocilo_o_delu_2013_web.pdf

Table 2 Success of constitutional complaints in 2009-2013

\begin{tabular}{l|l|l|l|l|l}
\hline Year & 2013 & 2012 & 2011 & 2010 & 2009 \\
\hline All cases received & 1031 & 1203 & 1358 & 1582 & 1495 \\
\hline Cases admitted & 23 & 47 & 26 & 74 & 58 \\
\hline Percentage of cases admitted (\%) & 2.2 & 3.9 & 1.9 & 4.9 & 3.9 \\
\hline All cases where final decision was made & 22 & 44 & 26 & 58 & 63 \\
\hline Complaint granted & 18 & 41 & 21 & 57 & 37 \\
\hline Complaint rejected & 4 & 3 & 8 & 1 & 26 \\
\hline $\begin{array}{l}\text { Percentage of successful cases out of all cases } \\
\text { where final decision was made (\%) }\end{array}$ & 81.82 & 93.18 & 80.77 & 98.28 & 58.73 \\
\hline
\end{tabular}

Source Annual Report of the Constitutional Court (2013)

The figures are from the Annual Report of the Constitutional Court (2013), p. 79

Slovenian courts, the numbers have to be read together; these are provided in Table 2.

2.8.4 See Sect. 1.3.4.

2.8.5 In my opinion, the perception of whether there is a gap in judicial review will depend to a great extent on the outcome of the recent, first request for a preliminary ruling made by the Constitutional Court (see Sect. 2.6.1) and especially on the course of the judicial dialogue.

2.8.6 The situation where different sets of rules would apply to a 'purely domestic' criminal case on the one hand and a case with an element of EU law on the other has been described using Ronald Dworkin's concept of 'checkerboard laws': 'laws that treat similar [cases] differently on arbitrary grounds' ${ }^{157}$ In light of the position of the scholarship that 'the Constitution of the Republic of Slovenia which, even in the circumstances of the full Slovenian EU membership, precludes any decrease in

${ }^{157}$ Erbežnik 2010, p. 216; Dworkin 1986, p. 179. 
the already existing constitutional standards of human rights protection', ${ }^{158}$ it seems inevitable that this issue will be addressed in Slovenian constitutional law. The gruesome example of the 'anticanon' Dred Scott case teaches us that historically, the existence of checkerboard laws has led to the absolute harmonisation of constitutional rights on the federal/supranational level. ${ }^{159}$ A possible alternative to the process of harmonisation is to institute a 'maximum standard' mechanism, as proposed by Ciril Ribičič: the law that provides the higher standard of human rights protection is applied. ${ }^{160}$

It should be noted that the equality clause in the Slovenian Constitution (Art. 14(1)) expressly guarantees equal human rights and fundamental freedoms to everyone regardless of their personal circumstances. If the EU human rights 'checkerboard laws' were to face a constitutional challenge based on Art. 14(1), the Constitutional Court would probably administer a strict proportionality test. ${ }^{161}$ It is likely that the Court would recognise mutual recognition among the Member States of the EU as a legitimate goal; however, the result of the balancing phase of the test is less predictable. If in weighing equality against mutual recognition the Court were to favour the former, this would mean adopting a maximum standard approach. If, on the other hand, the Court were to let mutual recognition prevail, it is hard to imagine that it would not accompany this move with a Solange type caveat. This, in turn, could contribute to a move for absolute harmonisation on the EU level.

\subsection{Other Constitutional Rights and Principles}

Implementation and minimum standards Boštjan Zalar has reported on how the implementation of the Asylum Procedures Directive, ${ }^{162}$ which defines minimum standards for the procedure in which refugee status is recognised and withdrawn, has led to the lowering of procedural standards in Slovenian refugee law. ${ }^{163}$ What is especially problematic is that these standards were established by the case law of the Slovenian Constitutional Court. Zalar has observed that, nevertheless, 'the Constitution itself and the existing case law of the Constitutional Court ... are not considered strong enough factors to force the executive and legislative branch of government towards the preservation of fundamental standards of human rights in the transposition of the [Directive]'. ${ }^{164}$

\footnotetext{
${ }^{158}$ Avbelj and Peršolja 2012, pp. 395-396. In a similar vein, see Novak 2004, p. 113.

${ }^{159}$ Dred Scott v. Sandford, 60 U.S. 393 (1857); Erbežnik 2012, p. 9; Halberstam 2015.

${ }^{160}$ Ribičič 2006, n. 7. See Halberstam 2015 for scepticism toward the 'higher standards' approach.

${ }^{161}$ CCRS U-I-425/06, UL, especially paras. 7 and 14.

162 Directive 2013/32/EU of the European Parliament and of the Council of 26 June 2013 on common procedures for granting and withdrawing international protection, [2013] OJ L 180/60.

${ }^{163}$ Council Directive 2005/85/EC on minimum standards on procedures in Member States for granting and withdrawing refugee status, [2005] OJ L 326/13.

164 Zalar 2008, p. 202.
} 
Choice of legal form for implementation Implementation of EU law has not brought about a significant change in the legal form in which legal norms are adopted. The constitutional rule under which the rights and duties of citizens and other persons may be determined by the National Assembly only by statute (Art. 87 Constitution, see Sect. 2.1.3; for the reflection of this provision in the rules on the ratification of treaties see Sect. 3.1.1) functions as a bulwark against a large-scale erosion of this kind. ${ }^{165}$ The rights and duties of individuals, however, are not the only type of legal norms for which the preferred form in the Slovenian legal system under normal circumstances would be a statute. When it comes to the assignment of different tasks to the various administrative organs, for example, the instructions found in the text of the Constitution (Art. 3 - separation of powers and Art. 120 - organisation and work in the state administration) are perhaps less direct than in Art. 87. Nevertheless, the Constitution also demands the use of a statute in a number of situations based on these clauses. In these types of cases, I believe it might happen that EU legislation, especially when the implementation deadline is approaching, would be implemented in the Slovenian legal system with the use of a sub-statutory instrument; however, later, the situation would be remedied in legislation. ${ }^{166}$

\subsection{Common Constitutional Traditions}

2.10.1 Traditions, by definition, originate in the past that is (or has been) passed on to the present. At first sight, the different historical characteristics of the Member States' constitutions (even beyond the strong/evolutionary divide, see Sect. 1.1.1), could lead us to a finding that there is little commonality in the Member States' traditions. In addition, a 'statistical' analysis of constitutional texts could easily turn into a cynical operation through which a minimum common denominator is to be identified, possibly leading to a reduction in the scope of European human rights law. At the same time, there is in my opinion nevertheless a message that is common to European constitutionalism as a whole: the rejection of the various totalitarian regimes that have abused public power and trampled on the integrity and dignity of the individual. In that sense, the constitutional traditions common to the

\footnotetext{
${ }^{165}$ I am grateful to Peter Pavlin for an informative discussion on this matter.

${ }^{166}$ I have been able to find one such example. In 2011, the Governmental decree on the implementation of legal acts of the European Union on the stepping up of cross-border cooperation, particularly in combating terrorism and cross-border crime (UL 18/11), in order to implement Council Resolutions 2008/615/JHA and 2008/616/JHA of 23 June 2008, assigned the execution of the relevant legal norms to the Ministry of Internal Affairs and designated the different units of the Police as national contact points. In 2013, the National Assembly adopted the new Police Tasks and Powers Act (UL 15/13). The Act, in Art. 161, assigned (again) the execution of the same norms to the Ministry and gave an authorisation to the Government to designate the national contact points pursuant to the Council Resolutions.
} 
Member States are legal expressions of the 'never again' cries that have followed periods of suffering and injustice in Europe. ${ }^{167}$ However, the text of Art. 6(3) TEU assigns a future-oriented purpose to the essentially retrospective concept of constitutional tradition. If it is to become a workable tool for the European courts, an approach will have to be identified that can apply historical lessons not only to the problems of which we are presently aware (e.g. data retention), but also to a host of yet unforeseeable challenges.

2.10.2 As discussed in Sect. 1.3.1, the principles of supremacy and direct effect of EU law have not been accommodated in Slovenian constitutional law explicitly, but with a rather more abstract provision according to which the legal acts of Art. 3.a. organisations (i.e. the EU) 'shall be applied in Slovenia in accordance with the legal regulation' of such organisations. ${ }^{168}$ The term 'legal regulation of such organisations' is most commonly interpreted as a device that accommodates supremacy and direct effect as structural principles of EU law within the Slovenian constitutional order. However, supremacy and direct effect are not the only principles of this rank. Zalar has recalled that respect for the common constitutional traditions, via Art. 6(3) TEU, also needs to be considered part of this 'legal regulation'. ${ }^{169}$ Indeed, the traditions inform the general principles governing the body of EU law. Were we to accept Zalar's reading of Art. 3.a, this would mean that pursuant to this article, EU law would have to be applied in Slovenia in accordance with respect for the common constitutional traditions. In effect, the Slovenian Constitution would bind EU law, insofar as it is applied in Slovenia, to the Member States' constitutions. A demand that fundamental rights, as they result from the common constitutional traditions, be respected by EU law, would then be based not only in the TEU, but also in the Constitution.

\subsection{Article 53 of the Charter and the Issue of Stricter Constitutional Standards}

2.11.1 In the domestic context, Constitutional Court Judge Ribičič has vocally opposed the practice of reducing the standard of human rights protection from the higher Slovenian constitutional level to the lower level of the ECHR. His reasoning is that the mission of the Council of Europe system of human rights protection, including the Convention and the Strasbourg Court, is to progressively ensure as high as possible minimum standards. To allow the states to drop from established standards would put an end to the positive development of human rights standards

\footnotetext{
167 Cf. Jambrek 2012, p. 32.

168 See above Sect. 1.3.1. Emphasis added.

169 Zalar 2005; Ahtik et al. 2014, p. 771. It is unlikely that this was the intention of the drafters who adhered to what I have referred to as the indefinable aesthetics of constitution making (Sect. 1.5.1); however, the more laconic the wording, the wider the field of interpretation.
} 
in Europe, amounting to abuse of the Convention as prohibited by Arts. 17 and 18 ECHR. ${ }^{170}$ Ribičič's position - in my opinion - accurately illustrates the perception of the ECHR as an absolute 'floor' among Slovenian lawyers. ${ }^{171}$

\subsection{Democratic Debate on Constitutional Rights and Values}

2.12.1 The Government took the usual steps to include the views of the public in the process of drafting the ZEKom-1, the implementing statute for the Data Retention Directive (see Sect. 2.4.1). It invited written comments and held two public consultation sessions. Throughout the dialogue with the public, fifty different entities (state authorities, businesses, individuals) submitted comments (however, the ZEKom-1 regulates the entire area of electronic communications, and therefore the consultation and the public discussion covered several issues beyond data retention). ${ }^{172}$ Concerns were repeatedly expressed regarding the provisions on data retention: whether data retention is truly necessary and whether the data retained indeed is useful in criminal investigations. The Government 'warned' the public that the Commission had lodged an action against Germany for non-implementation of the Directive, imposing a daily penalty of 315,036.54 EUR until implementation. ${ }^{173}$ In this sense, the implementation of the Data Retention Directive in Slovenia is an example of infringement proceedings for non-implementation echoing in domestic lawmaking procedures.

2.12.2-2.12.3 In Art. 260 TFEU proceedings, a Member State should be allowed to raise a 'constitutional defence' if it has failed to implement a directive because the implementation encountered serious constitutional obstacles articulated in the course of procedures established at the national level for the review of constitutionality, such as a procedure before the constitutional court or an analogous procedure in parliament. ${ }^{174}$

\footnotetext{
${ }^{170}$ CCRS U-I-272/98, UL 48/2003, Concurring opinion of Judge Ribičič, para. 8.

${ }^{171}$ See also Erbežnik 2014b and the discussion in Sect. 2.8.6. I would also like to acknowledge Mojca Plesničar's comment that all the practitioners and policy-makers interviewed in the framework of the study on the EAW (see Sect. 2.3) expressed fears that the standard of human rights protection was being reduced, towards a minimum common denominator.

172 Predlog ZEKom-1, Sect. I.2.3.d.

173 Ibid., Sects. III. and XIII.

${ }^{174}$ Bardutzky 2014a; see also Douglas-Scott 2002, pp. 411-413.
} 


\subsection{Experts' Analysis on the Protection of Constitutional Rights in EU Law}

2.13.1-2.13.3 I believe that to a certain extent Slovenia has faced a reduction in the standard of protection of fundamental rights as one of the consequences of European Union membership. Even though it was later successfully challenged before the ECJ, I believe that data retention can serve as an example. If this had been a purely domestic legislative project, it would have probably met insurmountable constitutional and democratic obstacles. But as it originated in the EU, it became part of the law in a very different atmosphere (see Sect. 2.12.1).

The reduction in standards is likely to be accepted among the citizenry as a trade-off for the benefits of integration. It is not to be dismissed that Slovenians, perhaps in contrast to other post-socialist Member States, have only recently begun to take advantage of the freedom of movement as a consequence of the economic crisis. This has made the benefits of membership very visible, especially among the young, educated and unemployed. In addition to the economic benefits of integration, I believe that governance on the European level is perceived as an additional check on national politics, with the latter enjoying relatively low respect among Slovenians.

While this may explain the forgiving attitude of the citizenry with regard to the reduction in standards, it does not supply an 'across the board' justification, at least not from the point of view of a constitutional lawyer. Whenever a supranational measure sits uncomfortably with domestic constitutional standards, the tension cannot simply be decided in favour of the former by saying the magic words 'effectiveness and unity'; a certain type of weighing is in order to ascertain whether the attainment of effectiveness and unity is needed sufficiently urgently as to justify the setting aside of constitutional standards.

Primarily, this is a matter for the courts. The recent 'new era' (to borrow the words of Giuseppe Martinico $)^{175}$ of preliminary references from constitutional courts to the ECJ is a promise of a more proactive attitude. Constitutional courts should not shy away from eloquently sharing their concerns and positions with the ECJ, substantiating them with national constitutional (case) law whenever they question the validity of EU secondary law, measured against the yardstick of fundamental rights. The ECJ should respect fundamental rights as informed by the constitutional traditions common to the Member States by building these arguments into the fundaments of its reasoning. ${ }^{176}$

\footnotetext{
${ }^{175}$ Martinico 2010, p. 221.

${ }^{176}$ As a small comparative side note, the US Supreme Court is known to let constitutional issues 'percolate' upward through the judicial system before it grants certiorari to one of the cases dealing with a particular issue and finally resolves the issue. In other words, before the Justices take a stand on a matter, they wish to have before them an array of the different possible solutions provided by the lower courts (and scholarly commentary!). Although in a much less hierarchical setting, this logic might make sense in the courts of the European Union as well. In situations
} 
This is not to idealise the conciliatory effects of judicial dialogue. Even in a situation where national constitutional courts are proactive and 'in the mood for dialogue' (to borrow more of Martinico's vocabulary), ${ }^{177}$ and the ECJ is responsive, it cannot be excluded that the standards are simply different. In mutual trust scenarios (such as Melloni), Daniel Halberstam's 'safety valve' proposal should be considered seriously. ${ }^{178}$ It remains open whether a similar solution can be found beyond scenarios involving mutual trust.

2.13.4 While in the scholarly quest for democracy and constitutionalism in the European Union attention on the Member State level is most often paid to national parliaments and (constitutional) courts, this focus of attention leaves out a crucial element: the administration. I acknowledge my personal bias in this matter, having previously served in a government department in a Member State; indeed my observations are based on my personal experience. Civil servants are important gatekeepers of the legal system and have enormous potential to prevent the adoption of unconstitutional norms. They draft legislation, including implementing legislation. At the same time, they exert influence on lawmaking at the European level, either directly or by way of expertise provided to the ministers. ${ }^{179}$ Again, based on my personal experience, the national constitution is far from a solemn monument to dwindling sovereignty; it is rather a workable tool, a source of arguments and a constant yardstick. We did not carry the heavy commentary of the Constitution to meetings in other departments to celebrate the country's sovereignty; we did it because in our work, we felt constrained by the constitutional court case law and scholarly opinion.

This account is of course part prescriptive and part descriptive. The claim here is not that all bureaucrats are staunch defenders of constitutionalist values. Whether the words 'the Constitutional Court will never allow it' gets the person who utters them in a meeting in a government department attention or gets him waved off by his interlocutors depends on a number of factors. The first factor is education, including continuous professional development. The second is the position and role of the professional civil service in the system of government. Third, the constitutional judiciary can (and has to) play a crucial role here by developing consistent

where a number of constitutional courts are seized of challenges to EU (implementing) legislation, procedural solutions could be established and a principle could be formulated according to which the ECJ would ensure that national constitutional courts' concerns are articulated, so that the ECJ can adequately respond to them. Perry 1991, pp. 230-234.

${ }^{177}$ Martinico 2010, p. 221.

${ }^{178}$ Halberstam 2015.

${ }^{179}$ Notably, Plesničar and Šugman Stubbs 2009, p. 212 recorded the discontent of Slovenian civil servants regarding the implementation of the EAW. The limited capacities of the (small Member State's) public administration mean that the persons in charge of the legislative drafting in the ministries are not the ones negotiating the instruments in EU lawmaking procedures; the small number of staff at the permanent representation to the EU prevents a sufficient specialisation among them; often, the transfer of information between the negotiators and the implementers is inadequate. 
and well-argued case law. Pythic holdings may be useful for disguising disagreement on the bench, but they are unlikely to strengthen the constitutionalist discourse among government lawyers. ${ }^{180}$ A transparent and consistent stance on the scope of the court's deference to the legislative branch is also likely to strengthen the legitimacy of the court's judgments by dispelling the impression among the readers of the case law that the court is acting on prevalently political motives.

\section{Constitutional Issues in Global Governance}

\subsection{Constitutional Rules on International Organisations and the Ratification of Treaties}

3.1.1 Ratification of treaties The Constitution distinguishes between international treaties that are to be ratified by the National Assembly and all other international treaties. Only the international treaties that are ratified by the National Assembly enjoy an elevated position in the hierarchy of legal acts: they are superior to all other legal acts except the Constitution, including statutes. International treaties that are not ratified by the National Assembly are only superior to sub-statutory legal acts.

The text of the Constitution does not delimit the two categories of international treaties further nor designate the body responsible for the ratification of 'sub-statutory' treaties. The legislature, by virtue of the Foreign Affairs Act (FAA), ${ }^{181}$ has vested the power of ratification of 'sub-statutory' treaties in the Government. The FAA further provides that the Government shall only ratify an international treaty if the incorporation of the treaty does not require statutory reform. Also, the Government only ratifies international treaties which:

- regulate questions that would, pursuant to the domestic legal order, fall within the Government's sphere of competences;

- are concluded in order to execute acts of international organisations that bind Slovenia, previously concluded international treaties and decisions of international cooperation in defence or internal affairs matters;

- regulate diplomatic and consular relations.

All other treaties need to be ratified by the National Assembly (Art. 75 FAA). The division of competences between the executive and legislative branches in the ratification of international treaties hence follows the dividing line drawn between the branches in domestic lawmaking. As was discussed above in Sect. 2.1.3, the Constitution demands that rights and duties be conferred by a statute, which accords

${ }^{180}$ In the context of the ECJ, a similar argument was recently presented in Bobek 2013, p. 207.

${ }^{181}$ UL 113/03, 20/06, 76/08, 108/09, 80/10. 
a relatively strong position to the National Assembly in terms of the breadth of its competences.

The ratification and publication of treaties is considered of constitutional importance; the Constitutional Court considers secret international agreements to be contrary to the fundaments of the Slovenian constitutional system. ${ }^{182}$

Transfer of powers Article 3.a Constitution does not refer to the European Union, but generically to 'international organisations' and provides a legal basis for transfer of the exercise of sovereign powers (see Sects. 1.2.1 and 1.3.1). To this day, this limb of Art. 3.a has only been used in relation to the European Union; however, this is not to say that it would be inapplicable to possible accession to international organisations in the future.

Article 3.a was also adopted in order to provide a legal basis for the accession of the Republic of Slovenia to the North Atlantic Treaty Organization (NATO). With that purpose, the text of the provision, in its second limb, also includes an authorisation for the state to 'enter a defensive alliance with [other] states', provided that such alliance is based on the respect for human rights and fundamental freedoms, democracy and the rule of law. In Slovenian constitutional law, membership in defence alliances thus represents a special category of Slovenian participation in mechanisms of global governance.

3.1.2 There has been no reform of this kind.

3.1.3 A few years before the EU-related reform of the Constitution, Ivan Kristan wrote in favour of expanding Art. 8 Constitution. While Kristan also proposed Art. 8 as the locus for the legal basis for accession to the EU, he would additionally in concreto anchor Slovenia's membership in some of the important international organisations (United Nations, NATO, Organization for Security and Co-operation in Europe) in Art. 8. ${ }^{183}$

3.1.4 See Sect. 1.5.3.

\subsection{The Position of International Law in National Law}

3.2.1 As mentioned above in Sect. 3.1.1, Slovenian constitutional law recognises two categories of international treaties with different positions in the hierarchy of legal norms. Statutes (and all other lower norms) also have to be in conformity with the 'generally valid principles of international law' (Art. 153(2)).

The Constitution also provides for the direct applicability of international treaties that have been ratified and published (Art. 8). Legal commentary adds that not all international treaties (or all provisions of a treaty) are suitable for direct

\footnotetext{
182 See above n. 128.

183 Kristan 2001, p. 4.
} 
applicability; only those with a self-executing character can be applied directly. ${ }^{184}$ The Constitution is silent on the form of ratification; as per Art. 169(1) PoDZ-1, treaties are ratified by statute (zakon).

3.2.2 It would seem that the dualism-monism dichotomy is of little use when attempting to conceptualise the position of the sources of international law in the Slovenian legal (constitutional) system. The way the Constitutional Court has worded its position on the purpose of Art. 8, namely that it 'defines, in principal terms, the relationship between the international legal order and the Slovenian legal order' ${ }^{185}$ has been interpreted as stemming from a position of dualism, namely recognising that these are two separate legal spheres. ${ }^{186}$ However, Urška Umek has also underlined the important elements of monism in the Slovenian system: first, treaties are incorporated into the legal system by simple adoption; secondly, treaties thus incorporated can be directly applicable. ${ }^{187}$

At the same time, Art. 8 cannot be read in isolation from the non-enumeration clause (Art. 15(5)) mentioned above (see Sect. 2.1.1). The position of the Constitutional Court is that by virtue of Art. 15(5), human rights and fundamental freedoms enshrined in international treaties that are in force in Slovenia are accorded 'constitutional rank' ${ }^{188}$ The tangible consequence of this position is that the Constitutional Court has in its history already issued a decision, which in its operative part established that the complainant's ECHR right had been violated. ${ }^{189}$ Upon finding that the text of the Constitution did not explicitly provide for the human right in question while the ECHR did, the Constitutional Court adopted the provision of the ECHR as premissa maior in the concrete case. It explained that the non-enumeration clause in Art. 15(5) Constitution is (inter alia) a response to the requirement of Art. 13 ECHR, the latter calling on States Parties to provide for effective remedies for violations of Convention rights.

Sketching the case of direct application of the ECHR by the Constitutional Court ultimately serves to illustrate the relative ineptitude of the concepts of dualism and monism when it comes to explaining the everyday interplay of the different instruments of human rights protection in action. There is enough support in the text of the Constitution for us to understand the Slovenian constitutional system as one open to international law. Seeing domestic and international law as two separate systems cannot be understood as an impediment to the perception of international law as a functional tool in the hands of the citizen and the judge. This openness

\footnotetext{
${ }^{184}$ Umek 2011, p. 133.

185 CCRS U-I-274/02, OdlUS XI, 204, para. 4.

186 See also CCRS Rm-1/09, para. 18. The Court used the phrase 'separate legal system' and immediately stressed the importance of international law for the interpretation of domestic law where the substance of domestic law originates from international law obligations.

187 Umek 2011, p. 135.

${ }^{188}$ Up-43/96, OdlUS IX, 141.

${ }^{189}$ CCRS Up-555/03, Up-827/04, Ur. list 78/2006.
} 
reaches its highest level in the case of international human rights law, with the recognition of the constitutional rank of the rights recognised by its instruments.

\subsection{Democratic Control}

3.3.1 In the case of international treaties that have to be ratified by the National Assembly, the National Assembly is involved not merely in the procedure of ratification, but also earlier, in the phase that precedes the negotiations. ${ }^{190}$

The internal aspect of the procedure to conclude an international treaty commences with the formulation of an official initiative to conclude a certain treaty. The initiative is sponsored by the Ministry of Foreign Affairs or another department of the Government and must already state the reasons in favour of conclusion of such a treaty and the draft positions of the future state delegation negotiating the treaty. It must nominate the members of the state delegation. If possible, a draft text of the treaty is to be attached together with a statement of the essential elements of the treaty. The initiative must provide an assessment of the financial impact of the treaty, of conformity of the treaty with valid law and whether the potential conclusion of the treaty will require legislative reform.

In any case, the Government must approve the initiative before negotiations can start. If an international treaty requires ratification in the National Assembly, the initiative is also sent to the Assembly's Committee of Foreign Policy for confirmation (Art. 70 FAA). The state delegation is bound by the positions in the approved initiative; should the negotiations diverge from the foreseen course, new positions need to be approved by the parliamentary committee (Art. 71 FAA).

The legislative branch and the directly elected representatives of the people are thus not only present, but are also given a veto power over a draft from the very beginning. Indirectly, the National Assembly will also be able to exert its influence over all the elements of the international treaty that are already included in the text of the initiative and thus co-decide the frame of the negotiations.

The National Assembly then plays the central role again when it comes to ratification of the treaty, i.e. the adoption of the ratification statute. The ratification statute will contain little more than the text of the international treaty. As further amendments to the text of the international treaty are inadmissible in this phase (Art. 169(4) PoDZ-1), the National Assembly expedites this quasi-legislative

${ }^{190}$ The response to question 3.3.1 refers to the National Assembly, the lower chamber of the Slovenian Parliament. The National Council as the upper chamber does not have any competences under the FAA. In practice, the National Council can still exercise the general powers that it has within the legislative function (Art. 97 Constitution) also with regard to ratification statutes. Thus the International Relations and European Affairs Committee of the National Council regularly scrutinises the international treaties ratified in the National Assembly and issues consultative opinions. At least in theory, the National Council could use its power of suspensive veto to prevent the ratification of a treaty approved by the National Assembly. 
procedure by following the procedural rules applicable to the emergency procedure (Art. 169(3) PoDZ-1). The emergency procedure is otherwise applied when for reasons of security, defence or due to a natural disaster, etc., the adoption of a statute cannot wait (Arts 143-144 PoDZ-1).

The National Assembly can adopt declarations to 'express general positions on issues of internal and external policies ... '. (Art. 110 PoDZ-1). Such declarations do not produce legal effects. The National Assembly has made use of this possibility infrequently, but it has used it, notably, to formulate the starting points of Slovenia's general strategy in international relations. ${ }^{191}$ With regard to global governance, the 1999 Declaration on the Foreign Policy of Slovenia, for example, listed the international organisations that Slovenia was planning to join at the time and the values and objectives that Slovenia would advocate in global politics. ${ }^{192}$ The instrument of declaration harbours potential for the increase of parliamentary participation in global governance affairs, especially in areas that are beyond the reach of the Parliament's power to ratify international treaties, e.g. the participation of Slovenia's representatives in international organisations. The process of adopting a declaration is an opportunity for the participation not only of the parliamentary opposition but also of civil society in the formulation of priorities, objectives and values that are to be pursued in foreign policy. Despite the fact that the text of the declaration is de facto drafted in the executive branch, the parliamentary procedure offers an appropriate platform that can attract an exchange of views across society. ${ }^{193}$ Whether the potential of the declaration to pursue these goals is developed to the full extent of course depends on the interest and capability of the parliamentarians to take an active role in global governance affairs.

3.3.2 The 2013 revision of the Constitution changed a number of defining features of the system of direct democracy in Slovenia. ${ }^{194}$ The reform was introduced after

\footnotetext{
${ }^{191}$ Declaration on the Foreign Policy of Slovenia (DeZPRS), UL 108/99. The National Assembly has issued declarations e.g. to formulate its position on the role of Slovenia in global climate change policies (Declaration on the Active Role of Slovenia in the Shaping of a New Global Climate Change Policy), UL 95/09) or to define Slovenia's position towards the countries of the Western Balkans (Western Balkans Declaration, UL 58/10).

${ }^{192}$ For example: 'In the area of global and regional international economic relations, the Republic of Slovenia will stand for solutions that will ensure full employment, higher quality of life and conditions for economic and social progress and development.' DeZPRS, Introduction.

${ }^{193}$ The 2014 coalition agreement between the political parties forming the government foresees a new declaration on foreign policy to be adopted by the National Assembly in 2015 by broadest possible consensus, following negotiations within the coalition and the parliament, a public debate and with consideration to other strategic documents of the state ...'. Coalition Agreement for the Parliamentary Term 2014-2018, p. 52, http://www.vlada.si/fileadmin/dokumenti/si/dokumenti/ 2014_Koalicijski_sporazum_parafiran.pdf.

${ }^{194}$ Constitutional Act amending Arts. 90, 97 and 99 of the Constitution of the Republic of Slovenia, UL 47/13. No revision was made to Art. 3.a (discussed above) nor to Art. 170 discussed above in Sect. 1.2.2. Albeit adopted in the same session of the National Assembly (24 May 2013), this is nevertheless formally a separate constitutional revision from the amendments to Art. 148 introducing the fiscal rule (discussed above in Sects. 1.2.1 and 1.5.1).
} 
the 2010-2012 'referendum wave' with a number of controversial decisions. ${ }^{195}$ The central element of the reform was the removal of the right of the National Council and the parliamentary minority to demand that a referendum be called (Art. 90(1)). Even after the reform, 40,000 voters can require the National Assembly to call a referendum as a matter of right. However, the previously extraordinarily strong role of the legislative referendum was also curtailed by limiting referendums ratione materiae, i.e. a referendum is no longer possible if the statute regulates certain questions. The list includes statutes ratifying international treaties. ${ }^{196}$

The proposal for the revision of the Constitution filed by a group of National Assembly deputies did not include ratification statutes in the list of limitations on legislative referendums. ${ }^{197}$ This additional limitation was added to the draft text following a suggestion by the expert group to the Constitutional Commission (see above Sect. 1.2.2), i.e. by constitutional lawyers rather than politicians. The expert group pointed out that the possibility to challenge the ratification of an international treaty is unusual in the comparative perspective, where treaties are rarely ratified by statute but rather by another type of parliamentary legal act (e.g. decree). ${ }^{198}$ For the expert group, it was the 'specific nature of the way international treaties are concluded' that called for referendums on ratification statutes to be banned. ${ }^{199}$ The expert group did not elaborate further how this specific nature collides with the possibility of a referendum. With the adoption of the Constitutional Act, there is now no opportunity in Slovenian constitutional law to challenge a decision of the National Assembly to ratify an international treaty by popular vote with a legally binding result. What remains is the general possibility for the National Assembly to call sua sponte for a non-binding, consultative referendum (Arts. 26-29 Referendum and Popular Initiative Act). ${ }^{200}$

195 Referendums were used not only in attempts to block economic reforms (see Skledar 2013) but also to prevent the coming into force of a family law reform that featured significant moves towards sexual orientation equality (Ribičič and Kaučič 2014, p. 904).

${ }^{196}$ Article 90(2) Constitution. In addition to ratification statutes, a legislative referendum is not allowed for

- statutes enacting emergency measures to ensure the defence of the state or security or that remedy damage caused by natural disasters;

- statutes on taxes and other compulsory contributions and on the statute for the execution of the state budget;

- statutes adopted to remedy an unconstitutional situation.

${ }^{197}$ Proposal of Katarina Hočevar et al. to initiate the procedure to amend the Constitution (13 September 2012, EPA 620-VI).

${ }^{198}$ See also above n. 190 with regard to the consequences of choosing statute as the form in which the Parliament ratifies treaties.

${ }^{199}$ Report of the Constitutional Commission of the National Assembly on the Proposal for the initiation of the procedure for an amendment of the Constitution of the Republic of Slovenia - UZ 90, 97, 99 (15 January 2013, EPA 620-IV), p. 13. See contra Vuksanović 2013, p. 13.

${ }^{200}$ As the expert group stressed, certain international treaties (Art. 3.a) could still be subjected to a referendum (the Art. 3.a referendum was discussed above in Sect. 1.4.2). 
Generally speaking, the referendum-related constitutional revision of 2013 was necessary to put a stop to the erosion of the power of representative democracy and the disproportionate rise of direct democracy, which was happening at the expense of constitutional democracy. ${ }^{201}$ However, this observation may not apply to the limitation imposed on referendums on ratification statutes. The laconic case for the elimination of referendums on ratification statutes makes it quite difficult to provide a clear-cut analysis of this reform. Two objections can be raised against the argumentation put forward by the expert group. First, in its case against the ratification statute referendum, it did not engage to a sufficient extent with the details of the ratification procedure in Slovenian foreign affairs law, especially not with the attention paid in diplomatic practice to the internal procedures of ratification. ${ }^{202}$ Secondly, while displaying consideration for the rules of international lawmaking, it failed to take into account the growing role of global governance, its impact on the everyday life of citizens and the erosion of constitutionalism to which it can lead.

Holding a referendum on a ratification statute may not be the optimal solution for the inclusion of direct democracy in domestic processes of participation in international lawmaking. It is very much a zero-sum game, capable of taking the negotiators as well as legislators by surprise at the very last moment when the expectations of international partners are the highest. The problem that we can observe is that the process of constitutional reform at this important moment was restrained from looking beyond the established categories and types of referendums. We could also speculate that the debates on the important domestic question of limiting referendums overshadowed the global governance dimension of the issue. Should the discussion be reopened, it would need to be liberated from exclusively using the language of Slovenian constitutional law while at the same time retaining the values of the Slovenian Constitution. This is the first precondition if we want to see the constituent power conjure up, on the national level, a robust system of decision making in foreign policy that strikes a workable balance between the pace dictated by the processes of globalisation on the one hand, and the requirements of constitutionalism and democracy on the other.

\subsection{Judicial Review}

3.4.1 The Constitution (Art. 160(2)) establishes a special procedure before the Constitutional Court where the Court issues a legally binding opinion on the constitutionality of a treaty. This procedure is somewhat different from the review of constitutionality of statutes and other norms. There are comparatively few subjects with legal standing: the President of the Republic, the Government, or one-third of the deputies of the National Assembly. In contrast to the procedures for

\footnotetext{
${ }^{201}$ Compare Ribičič and Kaučič 2014, p. 901.

${ }^{202}$ See below Sect. 3.4.1 and especially n. 209.
} 
the review of domestic norms (see Art. $24 \mathrm{ZUstS}$ ), there is no standing for the individual citizen. However, this is the only procedure for review of constitutionality that the President can initiate. This is likely related to the President's functions in the field of foreign affairs (Arts. 102 and 107 Constitution).

In contrast to the generally a posteriori procedures before the Constitutional Court, the opinion on an international treaty is issued a priori, 'in the process of ratifying an international treaty'. According to Nerad, this is to prevent the state, by ratification, from committing to international law obligations at odds with the Constitution, which would happen if there were self-executing legal norms in the treaty or if the treaty contained an obligation for the state to adopt an unconstitutional legal act. ${ }^{203}$

There have so far been five proceedings of review of an international treaty before the Slovenian Constitutional Court. Three of them were brought by the Government and two by the parliamentary minority. ${ }^{204}$ It is notable that the Constitutional Court has used 'interpretative decisions' three times in procedures of treaty review. ${ }^{205}$ These are decisions where the Court uses the operative part of its decision to declare how to interpret a contested provision in order for it to stay within the confines of the Constitution. The Court - at least within a priori procedures, much less so in a posteriori cases - has not shunned away from full review on the merits and has in that sense confirmed the position of Mirjam Škrk (herself formerly a judge of the Court) that

[w]hile the executive and legislative branches, also when it comes to a priori review, may expect a 'kind' attitude from the Constitutional Court, since the executive branch has already externally displayed the interest of the state to conclude the treaty under review, one should nevertheless not lose sight of the fact that the internal ratification of the international treaty is in the exclusive domain of the sovereignty of every state and subject to the decision of independent political (or judicial) organs that hold the respective competences. ${ }^{206}$

A priori review of the constitutionality of international treaties does not create a tension with the principle of pacta sunt servanda. This is mainly because in diplomatic practice, for Slovenia, the signing (or acceptance) of an international treaty does not yet represent consent to be bound. ${ }^{207}$ For a treaty to enter into force,

\footnotetext{
${ }^{203}$ Nerad 2011, p. 1441.

${ }^{204}$ Drenik 2013, pp. 77-78. There have also been attempts to contest a statute ratifying an international treaty. For example the Constitutional Court in Opinion Rm-1/09 reviewed the Croatia-Slovenia Arbitration Agreement, and later, after the Agreement had been ratified, in its Decision U-I-180/10, the ratification statute.

${ }^{205}$ CCRS Rm-1/97 (the European Accession Agreement), CCRS Rm-1/02 (the Agreement with the Holy See), CCRS Rm-1/09. Škrk 2006, p. 83.

206 Škrk 2006, p. 95.

207 Jager Agius 2013, p. 13. Signature is an expression of the state's intent to bind itself and not to act contrary to the purpose of the treaty. Should the treaty include a provision stating that the parties will be bound by it by force of signature, Slovenia has to sign the treaty with a 'subject to ratification' reservation. For Škrk, the Slovenian legal system does not recognise signature as a possible way of concluding an international treaty. Škrk 2006, p. 77.
} 
it needs to be ratified, and diplomatic practice distinguishes internal ratification (procedure in the National Assembly or the Government) and international ratification (exchange of ratification instruments between the states parties to the treaty) ${ }^{208}$ In that sense, the Art. 160(2) procedure falls squarely within the internal phase of ratification; the President will only issue a ratification instrument once the ratification statute has been published in the Official Gazette. ${ }^{209}$

\subsection{The Social Welfare Dimension of the Constitution}

3.5.1-3.5.2 Slovenia has not been subject to a programme of financial assistance. The constitutional implications of such a scenario were discussed hypothetically in the Constitutional Court's State Holding \& Bank Stability Referendum decision (see Sect. 1.3.2).

\subsection{Constitutional Rights and Values in Selected Areas of Global Governance}

The right to water In the past two years, demands have been voiced for the introduction of constitutional protection for the right to water. After the 2013 initiative of the National Council, proposals were formulated by groups of National Assembly deputies. A proposal submitted in 2014 failed, as the parliamentary term came to an end. At the time of preparing this report, a new proposal had been tabled. $^{210}$

The proposal refers to the experience of Greece, Portugal, Italy, Spain and France, where privatisation of the water supply system has led to an increase in the prices charged to the end users and to a decrease in the quality of water. In several

\footnotetext{
208 Jager Agius 2013, p. 16.

${ }^{209}$ Drenik 2013, pp. 64-65 (Table 1). With regard to the discussion above in Sect. 3.3.2, the same logic also applies to the legislative referendum (that is no longer admissible since 2013). The referendum would in any case be held after the adoption of the statute in the National Assembly and before the statute is promulgated by the President of the Republic (Art. 9 Referendum and Popular Initiative Act). In other words, it is impossible that the ratification statute would be struck down after the ratification instruments have been exchanged, thus violating Slovenia's international obligations. In this sense, the a posteriori legislative referendum is different from a posteriori judicial review of constitutionality. The former will always be held before the promulgation of the statute by the President and its publication in Uradni list. The latter can be filed at any time after the statute has entered into force and hence long after the ratification instruments have been exchanged and the treaty has entered into force.

${ }^{210}$ (2015, February 17). Znova predlog o ustavni zaščiti pitne vode (Again a proposal for constitutional protection of potable water). Delo. http://www.delo.si/novice/okolje/znova-predlog-oustavni-zasciti-pitne-vode.html.
} 
cases, privatisation of the water supply was demanded by the 'troika' as part of the conditionality for the country to receive financial support. It mentions Bolivia as an example of a country where privatisation of the water supply was one of the conditions put forward by the World Bank in order to extend a loan. The purpose of the initiative is thus to prevent changes in water regulation: the proposal mentions that Directive 2014/23/EU ${ }^{211}$ initially planned to liberalise the system of concessions for water. To that end, two paragraphs would be added to Art. 70 of the Constitution:

Everyone has the right to potable water.

Water sources that supply potable water and household water to the population shall be exploited in the form of a non-profit public service. ${ }^{212}$

Transatlantic Trade and Investment Partnership (TTIP) The TTIP has been met with criticism in Slovenia predominantly from environmentalist NGOs and trade unions. A number of them have jointly demanded from the government ministers that Slovenia reject the introduction of the investor-state dispute settlement (ISDS) mechanisms in the TTIP. This protest rejects any scenario according to which states would be exposed to legal claims against their public policies in arbitration tribunals. ${ }^{213}$ The concerns seems to have spread comparatively widely among the population, as Slovenia is among the countries where the number of signatures in support of the 'Stop TTIP' initiative has reached the 'country quorum' (Art. 7, Regulation 211/2011/EU). ${ }^{214,215}$

It seems that the concerns with regard to the TTIP are slowly making their way into the institutions of the state. The National Council, in early 2015, hosted an NGO-convened conference with the telling title of 'TTIP - are corporations to kidnap our future? ${ }^{216}$ In the Government commissioned study on the effects of the TTIP on the Slovenian economy, scholars warn of the unpredictable outcomes of the ISDS mechanisms and recommend maintaining the jurisdiction of national and

\footnotetext{
${ }^{211}$ Directive 2014/23/EU of the European Parliament and of the Council of 26 February 2014 on the award of concession contracts, [2014] OJ L 94/1. The 2014 proposal for constitutional reform mentioned that the pressure from the environmental NGO Right2Water which collected 1.5 million signatures demanding that water services be excluded from liberalisation (http://www. right2water.eu/news/vote-right-water-european-parliament-approaches) led Commissioner Michel Barnier to announce that the water services would be excluded from the scope of Directive 2014/ 23/EU. See Art. 12 ('Specific exclusions in the field of water') Directive 2014/23/EU.

212 Order of the National Council of 15 May 2013, No. 802-01/13-6; Proposal of Brane Golubovič et al. to initiate a procedure to amend the Constitution (20 March 2014, EPA 1861-VI).

${ }^{213} \mathrm{http} / / /$ www.umanotera.org/wp-content/uploads/2015/02/Javni-poziv-za-izklju\%C4\%8Ditevmehanizma-ISDS.pdf.

${ }^{214}$ Regulation (EU) No. 211/2011 of the European Parliament and of the Council of 16 February 2011 on the citizens' initiative, [2011] OJ L 65/1.

$215 \mathrm{https} / / /$ stop-ttip.org/signatures-member-states/.

${ }^{216} \mathrm{http}: / /$ www.umanotera.org/wp-content/uploads/2015/02/POSVET-vabilo-TTIP.pdf.
} 
European courts over TTIP disputes. ${ }^{217}$ Finally, the relevant committees of the National Assembly have adopted a position on the TTIP, the Comprehensive Trade and Economic Agreement with Canada and the WTO Trade in Services Agreement. The committees have called on the Government to negotiate for the exclusion of ISDS mechanisms from the agreements, to ensure that the agreements will not compromise the level of EU standards in environment, health and labour and social rights, and to defend the position that the Comprehensive Economic and Trade Agreement (CETA) and TTIP are mixed agreements. ${ }^{218}$

\section{References}

Ahtik M., Brkan M., Nendl Ž. (2014) In: Neergaard U., Jacqueson C., Danielsen J.H. (eds.) The Economic and Monetary Union: Constitutional and Institutional Aspects of the Economic Governance within the EU, The XXVI FIDE Congress in Copenhagen, 2014 Congress Publications Vol. 1. DJØF Publishing, Copenhagen, pp. 515-545.

Albi, A. (2015) Erosion of Constitutional Rights in EU Law: A Call for 'Substantive Co-operative Constitutionalism', Part 1. Vienna Journal of International Constitutional Law (ICL Journal) 9:151-185, http://ssrn.com/author=1246144.

Avbelj M. (2011) 44. člen (Article 44). In: Šturm L. (ed.) Komentar Ustave Republike Slovenije: dopolnitev - A (Commentary of the Constitution of the Republic of Slovenia - Supplement A). Fakulteta za podiplomske državne in evropske študije, Kranj, pp. 730-735.

Avbelj M. (2012a) Slovensko ustavno pravo v odnosu do prava EU (Slovenian constitutional law in relation to EU law). In: Kaučič I. (ed.) Dvajset let Ustave Republike Slovenije: pomen ustavnosti in ustavna demokracija (Twenty years of the Constitution of the Republic of Slovenia: the relevance of constitutionality and constitutional democracy). Pravna fakulteta Univerze v Ljubljani and Ustavno sodišče Republike Slovenije, Ljubljana, pp. 341-351.

Avbelj M. (2012b) Ustavni pluralizem v EU in Sloveniji (Constitutional pluralism in the EU and in Slovenia). Pravna praksa 31(6):6-9.

Avbelj M. (2013a) Trojka kot katalizator demokracije (The Troika as a democracy catalyst), 11.10.2013, http://www.insolvinfo.si/DnevneVsebine/Kolumna.aspx?Id=105711.

Avbelj M. (2013b) Trojka kot instrument regresije (The troika as an instrument of regression), 25.10.2013, http://www.insolvinfo.si/DnevneVsebine/Kolumna.aspx?Id=106676.

Avbelj M. (2013c) Konec ali začetek slovenskega ustavnega prava (The beginning or the end of Slovenian constitutional law). Pravna praksa 32 (1):6 et seq.

Avbelj M., Persolja N. (2012) Slovenia. In: Laffranque J. (ed.) The Area of Freedom Security and Justice, Including Information Society Issues, Reports of the XXV FIDE Congress Tallinn 2012, Vol. 3. Tartu University Press, Tallinn, pp. 555-574.

Bardutzky S. (2011) 149. člen (Article 149). In: Šturm L. (ed.) Komentar Ustave Republike Slovenije: dopolnitev - A (Commentary of the Constitution of the Republic of Slovenia Supplement A). Fakulteta za podiplomske državne in evropske študije, Kranj, pp. 1338-1343.

Bardutzky S. (2014a) Constitution as argument in infringement/enforcement proceedings: The case study of fines for delays in implementing the Data Retention Directive. Paper presented at the 'Assessing the EU's responsiveness to constitutional rights: Data Retention, Arrest

${ }^{217}$ Damijan et al. 2014. http://www.vlada.si/fileadmin/dokumenti/si/projekti/2015/TTIP/TTIP_Analiza_1_.pdf.

${ }^{218}$ National Assembly, Resolutions of the Joint Session of the EU Affairs Committee (22nd Session) and the Economic Committee (5th Session), 12 February 2015. 
Warrants and beyond' Work-in-Progress Seminar, University of Kent, Canterbury, 28-29 August 2014.

Bardutzky S. (2014b) The Timing of Dialogue: Slovenian Constitutional Court and the Data Retention Directive. http://verfassungsblog.de/timing-dialogue-slovenian-constitutional-courtdata-retention-directive/.

Bardutzky S., Fahey E. (2014) Who Got to Adjudicate the EU's Financial Crisis and Why? Judicial Review of the Legal Instruments of the Eurozone. In: Adams M., Fabbrini F., Larouche P. (eds.) The Constitutionalization of European Budgetary Constraints. Hart Publishing, Oxford, pp. 341-358.

Bele I. (2011) 27. člen (Article 27). In: Šturm L. (ed.) Komentar Ustave Republike Slovenije: dopolnitev - A (Commentary of the Constitution of the Republic of Slovenia - Supplement A). Fakulteta za podiplomske državne in evropske študije, Kranj, pp. 412-414.

Bobek M. (2013) Of Feasibility and Silent Elephants: The Legitimacy of the Court of Justice through the Eyes of National Courts. In: Adams M., de Waele H., Meeusen J., Straetmans G. (eds.) Judging Europe's Judges: The Legitimacy of the Case Law of the European Court of Justice. Hart, Oxford, pp. 197-234.

Brkan M., Nendl Ž. (2012) Slovenia. In: Laffranque J. (ed.) The Protection of Fundamental Rights Post-Lisbon, Reports of the XXV FIDE Congress Tallinn 2012, Vol. 1. Tartu University Press, Tallinn, pp. 775-800.

Bugarič B. (2012) Reševanje evra in začetek konca EU? (The saving of the euro and the beginning of the end of the EU?). Pravna praksa 31 (issue 5):3.

Čebulj J. (2011) 72. člen (Article 72). In: Šturm L. (ed.) Komentar Ustave Republike Slovenije: dopolnitev - A (Commentary of the Constitution of the Republic of Slovenia - Supplement A). Fakulteta za podiplomske državne in evropske študije, Kranj, pp. 1026-1031.

Cerar M. (2003a) Ustavna podlaga za prenos suverenosti in za vstop v obrambne zveze (Constitutional basis for a transfer of sovereignty and accession to defence alliances). Podjetje in delo 29:1463-1474.

Cerar M. (2003b) O nujnosti sprejetja novega 3.a člen Ustave (Of the necessity of adoption of the new Article 3.a of the Constitution). Evro PP 1(1):6-7.

Cerar M. (2011) Komentar k drugemu odstavku 3.a člena (Commentary of the first paragraph of Article 3.a). In: Šturm L (ed.) Komentar Ustave Republike Slovenije: dopolnitev - A (Commentary of the Constitution of the Republic of Slovenia - Supplement A). Fakulteta za podiplomske državne in evropske študije, Kranj, pp. 73-84.

Damijan J., Kostevc Č., Redek T. (2014) Vpliv Transatlantic Trade and Investment Partnership (TTIP) na slovensko gospodarstvo (The impact of the Transatlantic Trade and Investment Partnership (TTIP) on the Slovenian economy). Center poslovne odličnosti Ekonomske fakultete, Ljubljana. http://www.vlada.si/fileadmin/dokumenti/si/projekti/2015/TTIP/TTIP_ Analiza_1_.pdf.

Douglas-Scott S. (2002) Constitutional Law of the European Union. Longman, Harlow.

Drenik S. (2013) Mednarodne pogodbe v pravnem redu Republike Slovenije (International law treaties in the legal order of the Republic of Slovenia). In: Polak Petrič A., Jager Agius I., Zidar A. (eds.) Pravo mednarodnih pogodb. Fakulteta za družbene vede, Založba FDV and Ministrstvo za zunanje zadeve Republike Slovenije, Ljubljana, pp. 33-104.

Dworkin R. (1986). Law's Empire. Belknap Press, Cambridge.

Erbežnik A. (2008) Ustavno sodišče RS ter evropski nalog za prijetje in predajo ali 'kdo se boji Virginije Woolf' (The Constitutional Court of the Republic of Slovenia and the European Arrest Warrant or 'who's afraid of Virginia Woolf?'). Pravna praksa 27(1):II-VII.

Erbežnik A. (2010) Načelo vzajemnega priznavanja v okviru EU kot slaba utilitaristična rešitev (The principle of mutual recognition in the EU as a bad utilitarian solution). Dignitas 47/ 48:205-224. 
Erbežnik A. (2012) The principle of mutual recognition as a utilitarian solution, and the way forward. EuCLR 2(1):3-19.

Erbežnik A. (2014a) Mutual Recognition in EU Criminal Law and Its Effects on the Role of a National Judge. In: Peršak N. (ed.) Legitimacy and Trust in Criminal Law, Policy and Justice Norms, Procedures, Outcomes. Ashgate Publishing Limited, Farnham, pp. 131-152.

Erbežnik A. (2014b) Skupni standardi EU na področju kazenskega prava v primerjavi z nacionalnimi (ustavnopravnimi) standardi - Solange Reloaded (Common EU standards in criminal law in comparison to national (constitutional) standards - Solange Reloaded). Pravna praksa 33(26):II-VI.

Fišer Z. (2008) Izročitev, predaja in njuna uvedba v slovensko kazensko pravo (Introducing extradition and surrender into Slovenian criminal law). In: Šugman Stubbs K. et al. (eds.) Evropski nalog za prijetje in predajo: primerjalnopravni in nacionalni vidiki - Poročilo (The European Arrest Warrant: comparative and national perspectives - Report). Inštitut za kriminologijo pri Pravni fakulteti v Ljubljani, Ljubljana, pp. 19-59.

Grad F. (2007) Nova razmerja med parlamentom in vlado (New relations between the parliament and the government). Javna uprava 43(1):101-113.

Halberstam D. (2015) 'It's the Autonomy, Stupid!' A Modest Defense of Opinion 2/13 on EU Accession to the ECHR, and the Way Forward. German Law Journal 16:105-146.

Jager Agius I. (2013) Postopek sklepanja mednarodnih pogodb in drugih mednarodnih aktov priročnik (The procedure of concluding treaties and other international acts - a vademecum). In: Polak Petrič A., Jager Agius I., Zidar A. (eds.) Pravo mednarodnih pogodb (The law of treaties). Fakulteta za družbene vede, Založba FDV and Ministrstvo za zunanje zadeve Republike Slovenije, Ljubljana, pp. 3-28.

Jambrek P. (2012) Iskanje neusahljivega vira slovenske državnosti ter njegove ustavne identitete (The quest for the inexhaustible source of Slovenian statehood and its constitutional identity). In: Kaučič I. (ed.) Dvajset let Ustave Republike Slovenije: pomen ustavnosti in ustavna demokracija (Twenty years of the Constitution of the Republic of Slovenia: the relevance of constitutionality and constitutional democracy). Pravna fakulteta Univerze v Ljubljani and Ustavno sodišče Republike Slovenije, Ljubljana, pp. 23-33.

Jazbec B. (2014) Financial crises and the current situation in Slovenia. Address by Mr. Boštjan Jazbec, Governor of the Bank of Slovenia, at the Annual Conference of the Bank Association of Slovenia, Ljubljana, 18 November 2014. http://www.bis.org/review/r150205e.htm.

Jurič T. (2014) Evropski nalog za prijetje in predajo - kritična presoja zakonitosti ravnanja sodišča in Policije (The European Arrest Warrant - a critical assessment of the legality of actions of the courts and of the police). Pravna praksa 35(28):8-10.

Kaučič I. (2011a) Komentar k drugemu odstavku 3.a člena (Commentary on the second paragraph of Article 3.a). In: Šturm L. (ed.) Komentar Ustave Republike Slovenije: dopolnitev - A (Commentary of the Constitution of the Republic of Slovenia - Supplement A). Fakulteta za podiplomske državne in evropske študije, Kranj, pp. 84-88.

Kaučič I. (2011b) 170. člen (Article 170). In: Šturm L. (ed.) Komentar Ustave Republike Slovenije: dopolnitev - A (Commentary of the Constitution of the Republic of Slovenia Supplement A). Fakulteta za podiplomske državne in evropske študije, Kranj, pp. 1543-1548.

Kovačič Mlinar B. (2006a) Je ZENPP v neskladju z ustavo? (Is ZENPP unconstitutional?). Pravna praksa 25:(4):13-14.

Kovačič Mlinar B. (2006b) Pomanjkanje poguma pri odločitvi o pobudi za oceno ustavnosti ZENPP (A lack of courage in the decision regarding the initiative to review the constitutionality of ZENPP). Pravna praksa 25:(37):15-16.

Kresal B. (2011) 78. člen (Article 78). In: Šturm L. (ed.) Komentar Ustave Republike Slovenije: dopolnitev - A (Commentary of the Constitution of the Republic of Slovenia - Supplement A). Fakulteta za podiplomske državne in evropske študije, Kranj, pp. 1080-1085. 
Kresal Šoltes K. (2009) Primera Laval in Viking z vidika slovenske pravne ureditve avtonomije kolektivnega pogajanja (Laval and Viking case law from the perspective of the Slovenian law of autonomy of collective negotiations). Delavci in delodajalci 9:465-489.

Kristan I. (2001) Dimenzije 'evropskega člena' (Dimensions of the 'European clause'). Pravna praksa 20(31):4-5.

Križanič F. (2012) Fiskalna restrikcija $v$ času recesije (Fiscal restriction in the time of the recession). Gospodarska gibanja 2012(447). http://www.eipf.si/publikacije/gospodarskagibanja/2012/gospodarska-gibanja-447/fiskalna-restrikcija-v-casu-recesije/.

Kukovec D. (2014) Law and the Periphery. ELJ 21:406-428.

Martinico G. (2010) Preliminary References and Constitutional Courts: Are You in the Mood for Dialogue? In: Fontanelli F., Martinico G., Carrozza P. (eds.) Shaping Rule of Law through Dialogue: International and Supranational Experiences. Europa Law Publishing, Groningen, pp. $221-253$.

Mencinger J. (2006) Privatization in Slovenia. Slovenian Law Review 3:65-81.

Mitsilegas V. (2006) The constitutional implications of mutual recognition in criminal matters in the EU. CML Rev. 43:1277-1311.

Möstl M. (2010) Preconditions and Limits of Mutual Recognition. CML Rev. 47:405-436.

Nahtigal M. (2012) Evropski fiskalni pakt - preveč tog in omejevalen (The European Fiscal Compact - too rigid and limiting). Pravna praksa 31(12):II-VII.

Nerad S. (2011) 160. člen (Article 160). In: Šturm L. (ed.) Komentar Ustave Republike Slovenije: dopolnitev - A (Commentary of the Constitution of the Republic of Slovenia - Supplement A). Fakulteta za podiplomske državne in evropske študije, Kranj, pp. 1414-1462.

Nerad S. (2012) Recepcija prava Evropske unije v nacionalno ustavno pravo (Reception of EU law into national constitutional law). In: Kaučič I. (ed.) Dvajset let Ustave Republike Slovenije: pomen ustavnosti in ustavna demokracija (Twenty years of the Constitution of the Republic of Slovenia: the relevance of constitutionality and constitutional democracy). Pravna fakulteta Univerze v Ljubljani and Ustavno sodišče Republike Slovenije, Ljubljana, pp. 379-392.

Novak M. (2004) Slovenska ustavna identiteta v primežu evropskega prava - preliminarna razmišljanja (Slovenian constitutional identity in the vice of European law - preliminary thoughts). Revus 2(2): 95-115.

Oven B. (2014) Ustavno sodišče med sekundarnim pravom EU in ustavo Republike Slovenije: diplomsko delo (Constitutional Court between secondary EU law and the constitution of the Republic of Slovenia: thesis). Pravna fakulteta Univerze v Ljubljani, Ljubljana.

Pavlin P. (2011) 87. člen (Article 87). In: Šturm L. (ed.) Komentar Ustave Republike Slovenije: dopolnitev - A (Commentary of the Constitution of the Republic of Slovenia - Supplement A). Fakulteta za podiplomske državne in evropske študije, Kranj, pp. 1151-1163.

Perry H.W. (1991). Deciding to decide: Agenda setting in the United States Supreme Court. Harvard University Press, Cambridge.

Plesničar M.M., Modic M. (2007) The Constitutional Court of the Republic of Slovenia. Slovenian Law Review 4 (Dec. 2007):287-307.

Plesničar M.M., Šugman Stubbs K. (2009) Implementacija in percepcija načela vzajemnega priznavanja $\mathrm{v}$ slovenskem kazenskem pravu (Implementation and perception of the principle of mutual recognition in Slovenian criminal law). Zbornik znanstvenih razprav 69:203-228.

Ribičič C. (2003) Mozaik ustavnih sprememb: od slovenske ustavnosti k evropski (The mosaic of constitutional reform: from Slovenian towards European constitutionality). GV Založba, Ljubljana.

Ribičič C. (2006) Položaj slovenske ustave po vključitvi v EU (The position of the Slovenian constitution after the accession to the EU). Pravna praksa 25(29/30):II-VI.

Ribičič C., Kaučič I. (2014) Constitutional Limits of Legislative Referendum: The Case of Slovenia. Lex Localis - Journal of Local Self-Government 12:899-928. 
Rosenfeld M. (2009). The Identity of the Constitutional Subject: Selfhood, Citizenship, Culture and Community. Routledge, London.

Sadurski W. (2005) Rights Before Courts: A Study of Constitutional Courts in Postcommunist States of Central and Eastern Europe. Springer, Dordrecht.

Skledar Š. (2013) Changes proposed to referendum rules, 7. 4. 2013, https://www.eurofound. europa.eu/publications/article/2013/changes-proposed-to-referendum-rules.

Škrk M. (2006) Ustavnosodna presoja mednarodnih pogodb (Constitutional review of treaties). Revus 4(6):73-96.

Strban G. (2012) Ustavna zapoved socialne države ni pravno nezavezujoča norma (The Constitutional commandment of social state is not legally non-binding). Pravna praksa 31 (22):3.

Šturm L. (1998) Omejitev oblasti: ustavna izhodišča javnega prava (The limits on power: constitutional foundations of public law). Nova revija, Ljubljana.

Šturm L. (2002) 2. člen (Article 2). In: Šturm L. (ed.) Komentar Ustave Republike Slovenije (Commentary of the Constitution of the Republic of Slovenia). Fakulteta za podiplomske državne in evropske študije, Ljubljana, pp. 52-98.

Šturm L. (2011) 154. člen (Article 154). In: Šturm L. (ed.) Komentar Ustave Republike Slovenije: dopolnitev - A (Commentary of the Constitution of the Republic of Slovenia - Supplement A). Fakulteta za podiplomske državne in evropske študije, Kranj, pp. 1363-1370.

Šugman Stubbs K. (2008) Obseg sodne kontrole ENPP (The scope of judicial review of the European Arrest Warrant). In: Šugman Stubbs K. et al. (eds.) Evropski nalog za prijetje in predajo: primerjalnopravni in nacionalni vidiki - Poročilo (European Arrest Warrant: comparative and national perspectives - Report). Inštitut za kriminologijo pri Pravni fakulteti v Ljubljani, Ljubljana, pp. 136-141.

Šugman Stubbs K., Gorkič P. (2008) Empirična analiza postopkov v zadevah odločanja o ENPP (Empirical analysis of procedures in European Arrest Warrant cases). In: Šugman Stubbs K. et al. (eds.) Evropski nalog za prijetje in predajo: primerjalnopravni in nacionalni vidiki Poročilo (European Arrest Warrant: comparative and national perspectives - Report). Inštitut za kriminologijo pri Pravni fakulteti v Ljubljani, Ljubljana, pp. 155-186.

Šugman Stubbs K., Gorkič P. (2009a) Abuse of the EAW System. In: Keijzer N., van Sliedregt E. (eds.) The European Arrest Warrant in Practice. TMC Asser Press, The Hague, pp. 245-264.

Šugman Stubbs K., Gorkič P. (2009b) Denial of Guilt. In: Keijzer N., van Sliedregt E. (eds.) The European Arrest Warrant in Practice. TMC Asser Press, The Hague, pp. 229-243.

Šugman Stubbs K., Plesničar M.M. (2009) Mutual recognition in the context of Slovenian criminal law. In: Vernimment-Van Tiggelen G., Surano L., Weyembergh A. (eds.) The future of mutual recognition in criminal matters in the European Union. Ed. de l'Université de Bruxelles, Brussels, pp. 501-522.

Testen F. (2002a) 15. člen (Article 15). In: Šturm L. (ed.) Komentar Ustave Republike Slovenije (Commentary of the Constitution of the Republic of Slovenia). Fakulteta za podiplomske državne in evropske študije, Ljubljana, pp. 192-204.

Testen F. (2002b) 154. člen (Article 154). In: Šturm L. (ed.) Komentar Ustave Republike Slovenije (Commentary of the Constitution of the Republic of Slovenia). Fakulteta za podiplomske državne in evropske študije, Ljubljana, pp. 1024-1049.

Testen F. (2011) Komentar k tretjemu odstavku 3. a člena (Commentary on Article 3. a, Paragraph III). In: Šturm L. (ed.) Komentar Ustave Republike Slovenije - dopolnitev A (Commentary of the Constitution of the Republic of Slovenia - Supplement A). Fakulteta za podiplomske državne in evropske študije, Ljubljana, pp. 89-95.

Umek U. (2011) 8. člen (Article 8). In: Šturm L (ed.) Komentar Ustave Republike Slovenije: dopolnitev - A (Commentary of the Constitution of the Republic of Slovenia - Supplement A). Fakulteta za podiplomske državne in evropske študije, Kranj, pp. 131-145.

Vuksanović I. (2011) Ustava in ekonomska politika (Constitution and economic policy). Pravna praksa 30(41/42):18-20. 
Vuksanović I. (2013) Ustavne omejitve referenduma (Constitutional limitations of the referendum). Pravna praksa 32(2):13-14.

Zagorc S., Bardutzky S. (2010) Application of EU law in Slovenia: teething troubles of the blue-eyed boy. In: Lazowski A. (ed.) Application of EU Law in the New Member States: Brave New World. T.M.C. Asser Press, The Hague, pp. 421-451.

Zalar B. (2005) Prve izkušnje sodišča in sodnikovi pogledi na uporabo prava Evropske unije (First experiences of the court and the views of a judge on the application of European Union law). Pravna praksa 24(6): I-VIII.

Zalar B. (2008) Constitutionalisation of the implementing act of the procedures directive: the Slovenian perspective. European Journal of Migration and Law 10:187-217.

Zupančič B.M. (2002) 28. člen (Article 28). In: Šturm L. (ed.) Komentar Ustave Republike Slovenije (Commentary of the Constitution of the Republic of Slovenia). Fakulteta za podiplomske državne in evropske študije, Ljubljana, pp. 306-314.

Open Access This chapter is licensed under the terms of the Creative Commons Attribution 4.0 International License (http://creativecommons.org/licenses/by/4.0/), which permits use, sharing, adaptation, distribution and reproduction in any medium or format, as long as you give appropriate credit to the original author(s) and the source, provide a link to the Creative Commons license and indicate if changes were made.

The images or other third party material in this chapter are included in the chapter's Creative Commons license, unless indicated otherwise in a credit line to the material. If material is not included in the chapter's Creative Commons license and your intended use is not permitted by statutory regulation or exceeds the permitted use, you will need to obtain permission directly from the copyright holder.

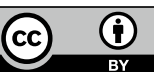

